OPEN ACCESS

Edited by:

Bheru Lal Salvi,

Maharana Pratap University of Agriculture and Technology, India

Reviewed by:

Edgar Antonio Barragán,

Salesian Polytechnic

University, Ecuador

Xochitl Cruz-Núñez,

National Autonomous University of

Mexico, Mexico

${ }^{*}$ Correspondence:

Md Arman Arefin

arefinarman@gmail.com;

md-arman.arefin@imt-atlantique.net

Specialty section:

This article was submitted to

Urban Energy End-Use,

a section of the journal

Frontiers in Sustainable Cities

Received: 11 June 2021

Accepted: 24 August 2021

Published: 23 September 2021

Citation:

Arefin MA, Islam MT, Rashid F,

Mostakim K, Masuk NI and Islam MHI (2021) A Comprehensive Review of

Nuclear-Renewable Hybrid Energy

Systems: Status, Operation,

Configuration, Benefit, and Feasibility.

Front. Sustain. Cities 3:723910.

doi: 10.3389/frsc.2021.723910

\section{A Comprehensive Review of Nuclear-Renewable Hybrid Energy Systems: Status, Operation, Configuration, Benefit, and Feasibility}

\author{
Md Arman Arefin ${ }^{1 *}$, Mohammad Towhidul Islam², Fazlur Rashid ${ }^{2}$, Khodadad Mostakim $^{2}$, \\ Nahid Imtiaz Masuk ${ }^{2}$ and Md. Hasan Ibna Islam ${ }^{2}$ \\ ${ }^{1}$ Safe and REliable Nuclear Applications, IMT Atlantique, Nantes, France, ${ }^{2}$ Department of Mechanical Engineering, Rajshahi \\ University of Engineering \& Technology, Rajshahi, Bangladesh
}

One of the biggest concerns of the present century is energy security and climate change. Further, studies suggest that there would be a huge lack of fossil fuels in near future. Moreover, in terms of cleaner production, the most popular and practiced way of power generation is renewable energy sources which are intermittent in nature, require large land area, and also dependent on geographic positions and climatic conditions. Besides, nuclear energy is also having some limitations including government policies and public apprehensions. To overcome these hurdles, these two carbon-free technologies can be integrated and form a nuclear-renewable hybrid energy system (N-R-HES). Literature related to the proposed systems is extremely rare and the systems are not yet welldeveloped. Keeping that into concern, this paper discusses the operation, status, prospects, and benefits of N-R-HES. Various possible integration techniques along with their operation are discussed in detail. Moreover, six aspects of interconnections are identified: electrical, thermal, chemical, mechanical, hydrogen, and information. The paper also discusses the reactor licensing, permitting procedures along the different benefits of N-R-HES. Additionally, research limitations and needs are identified for further exploration of the topic throughout the paper.

\footnotetext{
Keywords: nuclear energy, renewable energy, technology hybridization, polygeneration systems, hybrid energy systems
}

\section{INTRODUCTION}

The expected addition of 1 billion more people to the current population by 2030 could surely lead to a new headache to cope with the soaring energy demand (Suman, 2018). It is estimated that the population will be increased to about 8.5 billion by the year 2030 which may result in increasing the energy consumption up to $34 \%$ by 2035 (Melorose et al., 2015; Suman, 2018). The practice of using conventional fuels for energy supplies only, might not be enough for facing this huge percentage; rather a great impact on their depletion could be a serious issue. Besides this fast depletion, the uneven distribution of their sources will also result in the threaten for the ecological balancing (Upadhyay and Sharma, 2014). Therefore, both the scarcity of energy sources and the significant fluctuation of changing climate have become the biggest challenges for the upcoming generations. It is now widely accepted and a matter of serious concern that the economic development will be decelerated significantly unless extensive steps are adopted to mitigate both the over-dependency 
on fossil fuel and global warming (Reddy and Assenza, 2009; Apergis et al., 2010; Menyah and Wolde-Rufael, 2010; Hoque and Rashid, 2021). Thus, the development of an energy system should be implemented for lowering both the intensity of carbon and dependency on fossil resources through technological advancement. In this regard, many countries are investing for generating power by adapting sustainable solution which ensures the cleaner production. In this aspect, both renewable and nuclear energy possess a promising solution in the substantial reduction of carbon intensity. Many countries are now investing in these two sectors as a way of (a) reducing the dependency on fossil resources (b) ensuring energy security (c) facilitating fossil fuel by reducing the unstable foreign trade and (d) reducing the ecological imbalance (Toth and Rogner, 2006; Vaillancourt et al., 2008).

Between these two sources of cleaner energy supply, variable renewable energy sources (VRES) are representing the forefront of carbon reduction and technological advancement (Baker et al., 2018; Das et al., 2021). According to the Renewable Capacity Statistics 2019 [The International Renewable Energy Agency (IRENA), 2019], reported by International Renewable Energy Agency (IRENA), the world's renewable generation capacity has reached up to 2,351 GW by 2021. Harnessed energy from hydropower, wind, and solar possess the highest percentage of share which are $1,172,564$, and $480 \mathrm{GW}$, respectively. In the United States, of $70 \%$ newly built power plants provide electricity getting energy from the sources of solar and wind (Spector, 2021). Alongside this VRES, using nuclear energy is also getting popular for its high efficiency and cleaner production. Though uncertainties and reluctance were shown by few countries in the past, interests were found in investing and developing nuclear reactors for introducing a new diverse source of energy production to ensure and secure energy safety and generation of carbon-free energy (Adamantiades and Kessides, 2009).

However, the aspects of energy as predicted. Both Nuclear and renewable energies have respective pros and cons. Despite the capability of cleaner energy production, the major obstacle is their intermittency and dependency on the geographical location. However, efforts have been taken to mitigate the disrupting effect through increasing the electricity grid flexibility and introducing various buffering systems or flexible loads like battery electric storage (BES) (Baker et al., 2018). But these systems bring more complexity in operation which results in extra cost involvement. Moreover, though harnessing energies from renewable sources are thought to be ecologically friendly, the unavoidable stress on the environment while mining is considerable. Even during building the renewable energy-based power plant, negative impact inflicted upon the surrounding habitats and nearby wildlife. Its large land requirement for mass-scale production also adversely affects the surroundings. In terms of nuclear energy, though it was widely proven and accepted as highly efficient cleaner energy production, many countries and environmentalists had shown lethargies due to the possible melting of the reactor which may lead to a serious catastrophe for surrounding habitats and wildlife (Suman, 2018). Moreover, improper policies and regulations for dumping the radioactive nuclear waste and other fissile nuclear fuel used in which may results in a serious harmful effect (Adamantiades and Kessides, 2009).

However, any means of power generation consists of some drawbacks and possible threats. Since every energy source has its own trade-offs, optimized incorporation among the sustainability, economic growth, energy demand, and security need to be struck to facilitate technological advancement. Almost all nations around the world have begun inspecting nuclear and renewable energy with a view to lessen the overdependence on crude oil, curtailing currency fluctuations, improving energy security concerning fossil fuels from foreign areas, and degradation of ecological order (Vaillancourt et al., 2008). Renewable sources of energy are not permanent and due to public fears and subsequent government policies, the prospect of nuclear energy is also uncertain. So, this issue could be overcome with a new system called the "Nuclear-renewable hybrid energy system (N-R-HES)." Optimizing the operation of hybrid systems would satisfy the increasing demand for grid flexibility, while at the same time maximizing economic benefit by allowing the operation of nuclear and renewable power sources. The reactor using nuclear power is combined with renewable energy generation in this type of integrated system and can handle several types of issues, for instance, the flexibility of the grid, global warming, and clean energy, optimal return on investment capital, energy security, and public concern. Typically, one or perhaps two power sources (e.g., biomass co-fringing with coal) are used to generate both electricity and occasionally effective heat (cogenerating systems), and hybrids of this kind would be substantially different from traditional systems. These new innovations can also be employed to develop hybrid energy systems having new features which include (a) improving the flexibility of the grid, and (b) provide the possibility for the use of traditional basic loading systems to generate economical load tracking and provide multiple forms of support. However, research and study related to N-R-HES are extremely rare since it is a very new technology and the technology is not mature yet. Extensive research and review are necessary on the basis of interconnections, configurations, reactor design, feasibility, listening, and permitting of plants and benefits. Keeping these into mind this paper is constructed with a detailed overview of N-R-HES.

This study investigates a potential premise to achieve mentioned aims- integrating both renewable and nuclear systems, efficient and reliable low-carbon energy facilities combined with industrial processing and renewable technologies, and find demerits when they work individually. A detailed overview of hybrid system configurations and interconnections is included in this study along with proper selection criteria of technologies and components. Based on these criteria, recent prior references were defined, searched, and added for this review. In addition, a brief discussion about reactor and plan licensing, benefits, economic analysis, and available evaluation technologies are also included in this study. 


\section{COMMON ENERGY SYSTEMS}

\section{Renewable Energy System}

A solution to lessen the use of fossil fuels and emissions is to deploy renewable energy resources on a large scale. Using 100\% renewable energy resources directly contributes to the United Nation's sustainable development goal no. 7 (affordable and clean energy for all). The most popular renewable sources are solar, wind, tidal, wave, biofuel, and geothermal energy. In the present era, wind and solar photovoltaics (PV) have experienced a radical cost reduction. Because of public and private research \& development (Kavlak et al., 2018) and advanced materials and higher efficiencies, PV has achieved the highest cost reduction (Trancik and Cross-Call, 2013) mean. Besides PV, concentrated solar power and wind are also expected to become cheaper in near future. However, research related to the cost of tidal, geothermal, and wave energies are limited.

Nowadays, the $100 \%$ renewable energy concept is becoming very popular among researchers and stakeholders, for instance, Denmark's goal is to become a country with zero net emission by the year 2050 (Hansen et al., 2019). Further, many other countries like Bangladesh, Ethiopia, Ghana, Vietnam, Cambodia are trying to achieve a $100 \%$ renewable energy concept by $2045-$ 2050 (Hansen et al., 2019).

\section{Hybrid Renewable Energy System}

A hybrid renewable energy system (HRES) is broadly defined as the merge of two or more renewable energy sources or one or more sources of renewable energy with one/more sources of conventional energy (Amer et al., 2013). The intention of adapting HRES is to ensure the maximum usage of renewable energy sources and increase their efficiency. There are several parameters that must be considered while using hybrid systems for generating electricity. Studies (Ma et al., 2018a; Ramesh and Saini, 2020) suggest that HRESs are economically viable when using off-grid in remote locations. However, climatic parameters influence the adaptability and profitability of HRES, for instance, photovoltaic-diesel hybrid systems are only ideal in areas with hot climatic conditions (Table 1). In this case, when photovoltaic panels are unable to provide power due to weather conditions, the diesel system would contribute solely to meet local demand nowadays, because of the increased conventional fuel cost and abundant supply of renewable energies, HRES systems are becoming very popular in developing countries. Photovoltaic (PV)-wind system is mostly used in Indonesia, Iran, India, and China due to their metrological condition. China and Iran receive high-velocity wind flow in offshore regions year-round. Most hybrid systems with PVs are seen in Sudan, India, Pakistan, and Saudi Arabia because of their high solar radiation and hot climatic conditions. At present, besides PV and wind, other sources of renewable energy, for example, biomass and biogas are also being integrated with hybrid renewable energy systems.

\section{Nuclear Energy System}

Nuclear energy is a type of energy that is harnessed from a nuclear reaction where water is turned into steam by the heat released from the reaction which eventually rotates a turbine to produce electricity. Nuclear energy can be achieved from fission, fusion, or nuclear decay reaction. However, nuclear energy is not being used in transportation yet, but it has the potential and can be used in transportation (Agyekum et al., 2020). Study (Adler et al., 2020) suggests that the use of nuclear energy is supposed to reduce pressure on fossil fuel and a potential way of reducing greenhouse gas emissions. Besides renewable energy, nuclear energy is considered a potential source of global economic decarburization as it is a low-carbon technology. However, safety and the release of radioactive materials are the major issues while considering the utility of nuclear energy and systems. Till now, there have been several nuclear accidents such as Chernobyl (1986) and Fukushima Daiichi (2011) incidents which released a high amount of radioactive isotopes into the environment. Nevertheless, it is a matter of relief that the International Atomic Energy Agency (IAEA) is continuously monitoring and researching the growth of nuclear energy and systems. Besides safety and security, the organization also ensures that nuclear energy is not being used for military purposes (Pravalie, 2014).

To decrease $\mathrm{CO}_{2}$ discharge in accordance with the $2{ }^{\circ} \mathrm{C}$ threshold, a large share of almost $13 \%$ of energy must be provided by nuclear energy to reach this threshold by 2050 (Nuclear Energy Agency, 2015). This percentage equates to about a $2.5 \mathrm{Gt}$ $\mathrm{CO}_{2}$ reduction per year. However, a large amount of investment is necessary to reach this goal. Statistics identified that to reach a capacity of $930 \mathrm{GW}$, an investment of $\sim \$ 4$ trillion would be necessary. Almost half of the money would be required for decommissioning of the facilities and extending the lifetime of the plants in the US and Europe. Besides these two regions, China will have to invest roughly a quarter (1/4) of the total money required to reach the threshold.

As of 31 December 2019, a total number of 433 reactors are in operation worldwide, which corresponds to a generation of 392,098 MW of electricity. Further, 54 reactors are under construction, which corresponds to a production of 57,441 MW of electricity (Getty and National University of Singapore, 2020). Among the running reactors, almost $66 \%$ have been in operation for more than 30 years. Bangladesh has recently established two nuclear reactors of a total of 2,000 MW in Ruppur. So far, 28 states have expressed interest in nuclear power and among them, 18 states have already started research and study regarding nuclear power and 4 have already started building nuclear infrastructure (Getty and National University of Singapore, 2020).

\section{METHODOLOGY}

\section{Sourcing and Analyzing of Articles}

This study utilized a systemic review of published relevant literature. The method provided by Arefin et al. (2021) was followed in this study. The following steps were considered while conduction the systemic review (Amui et al., 2017).

1. Survey for finding related articles.

2. Implementation of structured method (coding) for sampling and categorizing gathered articles.

3. Implement the developed system to identify best results.

4. Opportunities and gaps should be analyzed for future studies. 
TABLE 1 | HRES technologies implemented around the world.

\begin{tabular}{|c|c|c|c|c|}
\hline System type & References & Location & Output/advantages & Remarks \\
\hline $\begin{array}{l}\text { Solar photovoltaic and } \\
\text { biogas generator with } \\
\text { pumped hydro energy } \\
\text { storage }\end{array}$ & $\begin{array}{l}\text { Heydari and Askarzadeh, 2016; } \\
\text { Rahman et al., 2016; Singh and } \\
\text { Baredar, 2016; Ahmad et al., 2018; } \\
\text { Sawle et al., 2018; Zhou et al., } \\
\text { 2018; Das et al., 2019; } \\
\text { Murugaperumal and Raj, } 2019\end{array}$ & $\begin{array}{l}\text { Canada, India, Pakistan, } \\
\text { Africa }\end{array}$ & $\begin{array}{l}\text { This is a } 100 \% \text { renewable energy based } \\
\text { HRES system. The noteworthy benefit of } \\
\text { this system is the reduced price of PV } \\
\text { system. This type of system is extremely } \\
\text { useful in Sub-Saharan regions. }\end{array}$ & $\begin{array}{l}\text { Zero emission system with } \\
\text { low installation price. }\end{array}$ \\
\hline PV-wind & $\begin{array}{l}\text { Chong et al., 2011; Fulzele and } \\
\text { Dutt, 2012; Askarzadeh and dos } \\
\text { Santos Coelho, 2015; Kalinci et al., } \\
\text { 2015; Maleki et al., 2016; Khare } \\
\text { et al., 2017; Anoune et al., 2018; } \\
\text { Shezan et al., 2018; Singh and } \\
\text { Fernandez, 2018; Awan, 2019; } \\
\text { Krishan and Suhag, 2019; Husain } \\
\text { and Shrivastava, 2020; Mayer et al., } \\
\text { 2020; Wang et al., 2020 }\end{array}$ & $\begin{array}{l}\text { Indonesia, Iran, Malaysia, } \\
\text { India, China, Saudi Arabia }\end{array}$ & $\begin{array}{l}\text { This is the simplest form of } 100 \% \text { HRES } \\
\text { system. The main disadvantage of this } \\
\text { system is the compatibility of voltage. The } \\
\text { PV system responses faster than the } \\
\text { wind system. However, some recent } \\
\text { studies (Chaib et al., 2016; Anoune et al., } \\
\text { 2018) have suggested some methods to } \\
\text { mitigate this problem. }\end{array}$ & $\begin{array}{l}\text { This system is effective } \\
\text { also in hot climatic regions. } \\
\text { More research is necessary } \\
\text { to establish a satisfying } \\
\text { control bus. }\end{array}$ \\
\hline $\begin{array}{l}\text { Solar-photovoltaic with } \\
\text { wind turbine and diesel } \\
\text { engine }\end{array}$ & $\begin{array}{l}\text { Khan et al., 2018; Belfedhal et al., } \\
\text { 2019; Elkadeem et al., } 2019\end{array}$ & Sudan, Saudi Arabia & $\begin{array}{l}\text { In this system, two renewable energy } \\
\text { sources are integrated with a } \\
\text { non-renewable source. The main } \\
\text { advantage of this system is that diesel } \\
\text { engine can fulfill the energy demand if } \\
\text { due to metrological conditions PV and } \\
\text { wind system don't work. }\end{array}$ & $\begin{array}{l}\text { The diesel engine only runs } \\
\text { when wind/PV system is } \\
\text { not able to fulfill the load } \\
\text { demand. }\end{array}$ \\
\hline $\begin{array}{l}\text { Hydrogen fuel cell (HFC) } \\
\text { and solar photovoltaic } \\
\text { (SPV) hybrid }\end{array}$ & $\begin{array}{l}\text { Singh et al., 2017; Natarajan et al., } \\
2019\end{array}$ & India & $\begin{array}{l}\text { Nowadays, proton exchange membrane } \\
\text { fuel cells are playing significant role is } \\
\text { power generation. This type of fuel } \\
\text { cell/PV systems are not widely seen. } \\
\text { Limited numbers of literature are found } \\
\text { and this system is currently can be seen } \\
\text { mainly in India and some other regions. }\end{array}$ & $\begin{array}{l}\text { This is a zero-emission } \\
\text { system. The system might } \\
\text { have very long-life cycle. } \\
\text { However, more research is } \\
\text { necessary to increase the } \\
\text { efficiency of hydrogen fuel } \\
\text { cell. }\end{array}$ \\
\hline PV-diesel & $\begin{array}{l}\text { Kruangpradit and Tayati, 1996; } \\
\text { Bernal-Agustín and Dufo-López, } \\
\text { 2009; Halabi and Mekhilef, 2018; } \\
\text { Kasaeian et al., } 2020\end{array}$ & Thailand & $\begin{array}{l}\text { The vision of this type of HRES is to } \\
\text { supply electricity to customers for } 24 \mathrm{~h} \text {. In } \\
\text { optimum condition, the diesel system can } \\
\text { work when PV system fails to meet the } \\
\text { demand. }\end{array}$ & $\begin{array}{l}\text { The major disadvantage of } \\
\text { this type of system is the } \\
\text { necessity of large amount } \\
\text { of area for PV arrays. }\end{array}$ \\
\hline $\begin{array}{l}\text { Biogas + biomass + solar } \\
+ \text { wind }+ \text { fuel cell }\end{array}$ & $\begin{array}{l}\text { Asplund, 2008; Anwar et al., 2020; } \\
\text { Suresh et al., 2020; Vendoti et al., } \\
2020\end{array}$ & India & $\begin{array}{l}\text { This is the most advanced type of HRES } \\
\text { system. It consists of five individual } \\
\text { systems which are integrated together. } \\
\text { This system is mainly implemented in } \\
\text { rural areas. Cited researches suggest that } \\
\text { this the most dependable type of HRES. }\end{array}$ & $\begin{array}{l}\text { Because of having multiple } \\
\text { system together, this HRES } \\
\text { is hard to optimize and } \\
\text { control. Therefore, more } \\
\text { research should be } \\
\text { conducted focusing on } \\
\text { proper design and } \\
\text { optimization. }\end{array}$ \\
\hline
\end{tabular}

In this study, three well-known article sources were considered (i) google scholar, (ii) Scopus, and (iii) web of science. The publication year of the articles were not considered in this study, however, authors tried to incorporate only recently published articles. Almost $70 \%$ of the all collected articles were cut off because of low or lack or relevancy. After that some more articles were excluded to keep only recently published articles. However, some old articles are included which authors found extremely important and unavoidable. In short, the following elements were combined in the whole article selection process.

i. Keywords: Renewable energy, nuclear energy, hybrid nuclear-renewable technology, NRHES systems, polygeneration systems, hybrid energy systems

ii. Language: English (only) iii. Boolean operators: OR and AND

iv. Publication year: not considered

v. File type: article and conference proceedings and reports (in exceptional cases trusted websites were considered).

\section{NUCLEAR-RENEWABLE HYBRID ENERGY SYSTEM}

By integrating renewable sources with nuclear energy can have a great impact on uplifting the energy demand. Further, emissions of fewer power sources such as wind, solar, tidal, wave, and geothermal play a great role in the reduction of greenhouse gas. Therefore, N-R-HES is a proposed solution for fulfilling energy 


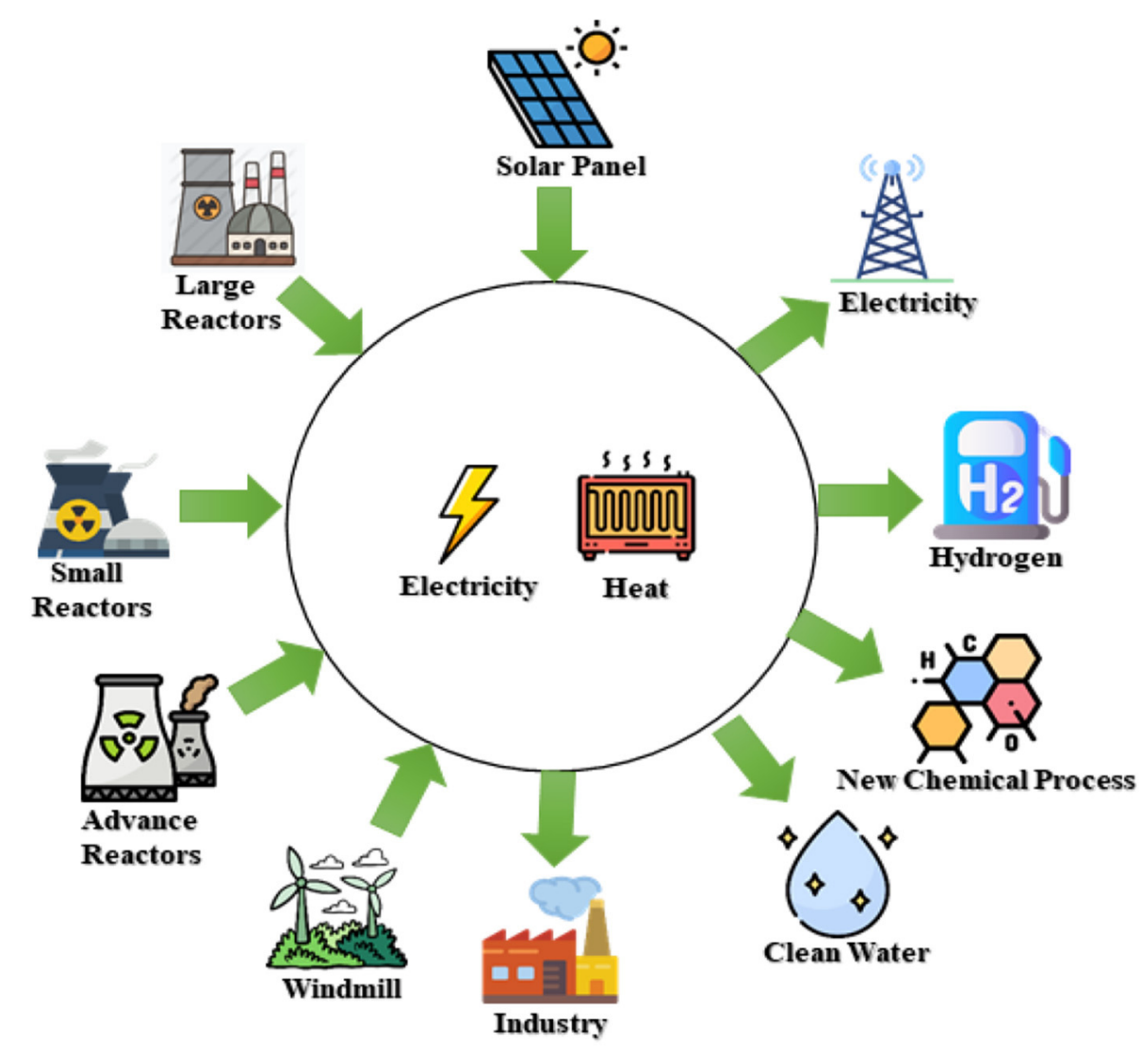

FIGURE 1 | Maximizing energy utilization through novel systems integration.

demand and reducing emissions (Redfoot and Borrelli, 2018). The benefits of N-R-HES co-locate the advantages including lessening system expenses while growing economic viability by versatility both the way of producing energy and products (fuel) generated. Figure 1 illustrates the advantages of integrating different novel systems for maximizing energy. By combining renewable energy sources with nuclear power plants, the future energy demands can be fulfilled to a certain level, and also economic feasibility can be achieved; for example, if natural gas price increases suddenly, this N-R-HES system can be a suitable alternative to replace the dependency on natural gas.

It is not possible that only nuclear energy would fulfill the future demand (Suman, 2018). For mitigating this colossal demand, people have to move toward N-R-HES. Incorporating an appropriate industrial process, hybrid nuclear energy systems facilitate savings from different categories of products and evade economical insolvency. The initiation of a most recent version of reactors meets the criterion of conducting a large complex chemical process that resembles the required energy output. Furthermore, such a hybrid system will lessen the combined price of variable renewable energy sources.

Supplying continuous power with a hybrid system and grid flexibility, these systems can give an upright supply of energy. It is anticipated that suggestible nuclear renewable hybrid system components will operate similarly to how they have been operated independently before. However, for the cause of additional integration difficulty, some major technical issues like interconnection, redundant system issues, and core components will evolve.

\section{Core Components}

The design basis of an N-R-HES depends on case-specific industrial uses, technical requirements, and economical drivers associated with the system maintenance. The system should be tailored to dynamically optimize the use of electrical and thermal energy. Figure 2 illustrates the core components of N-R-HES, which will be discussed below sections.

A nuclear reactor will generate baseload heat and power, and energy can be harvested without greenhouse gas emissions. To cover the operating costs, the nuclear system should function at a high-capacity factor. Table 2 illustrates different reactors used in NR-HES. If the reactor is operated near steady-state design conditions, it would perform more proficiently and maintenance cost would be minimalized (Orr, 2015). Based on full net loads and optimum earnings, generated heat by reactor would be appropriate to use for industrial processes and storage for power generation and fuel production. 


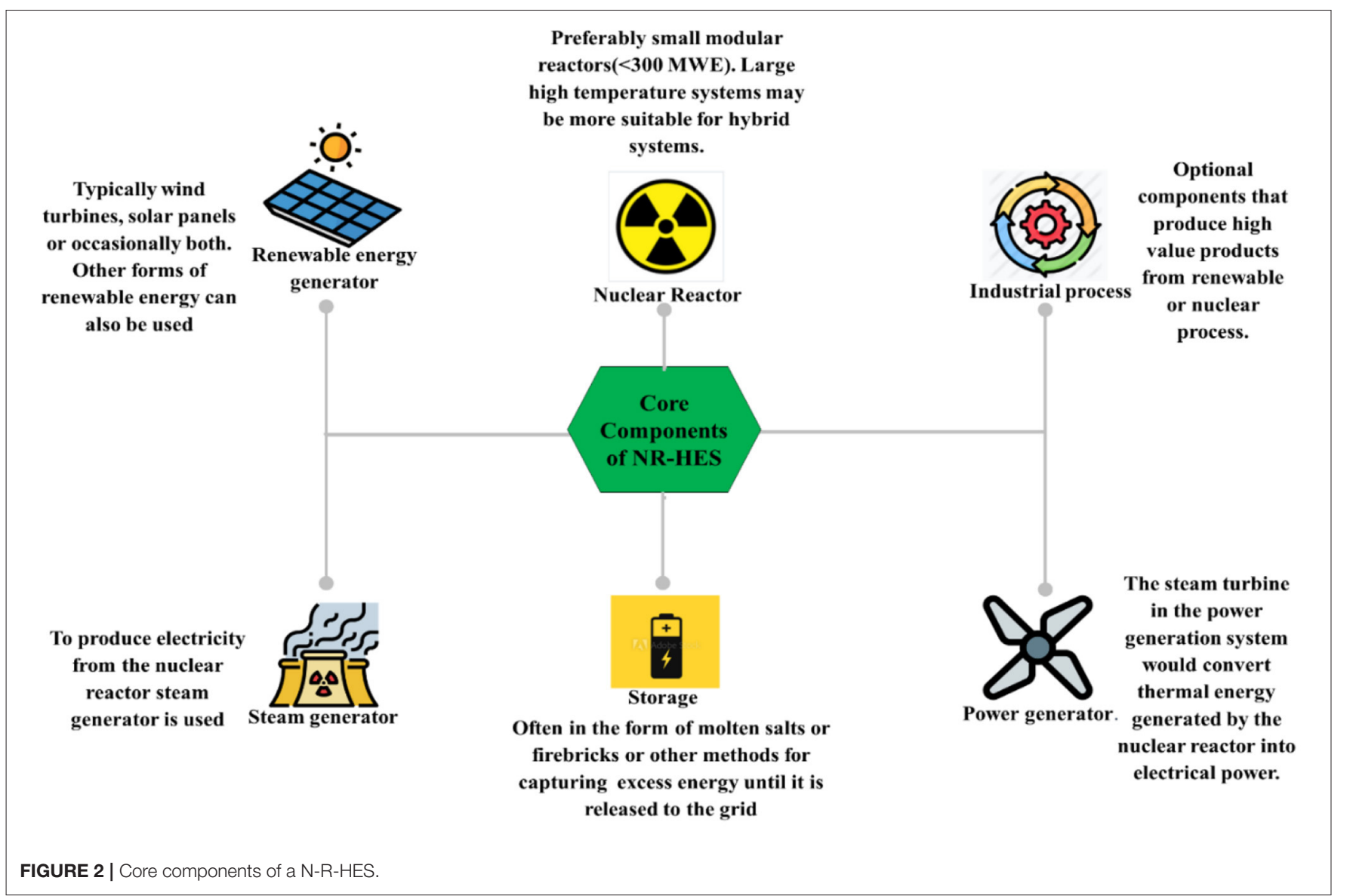

There are several components in a nuclear reactor including fuel, moderator, control rod, coolant, etc. It can be seen from Table 2 that Uranium or Uranium compounds limited to a certain percentage are used in the maximum reactor as most reactors need to be shut down for refueling (World Nuclear Association, 2021). The Reaktor Bolshoy Moshchnosti Kanalniy (RBMK) and Canada Deuterium Uranium (CANDU) reactors have reactor core enclosed by the pressure tubes instead of a pressure vessel and can be refueled by detaching each pressure tube, respectively. The Uranium dioxide can be enriched to 3.2\% in only a pressurized water reactor with zirconium alloy cladding. Equivalent uranium configuration has been found in natural uranium when excavated $(0.7 \% \mathrm{U}-235$, over $99.2 \% \mathrm{U}-238)$, where affluent uranium has the percentage of the fissile isotope (U235) amplified by a process called enrichment (World Nuclear Association, 2021). The coolant of the reactor maintains several parameters like pressure and heat extraction. In advance gas cool reactors (AGR) and Magnox, $\mathrm{CO}_{2}$ is heated in the coolant by fuel, raising steam in a steam generator. On the other hand, in a pressurized water reactor (PWR), heat is extracted by a steam generator. Steam is raised in a steam generator when light water is pumped into it. In a boiling water reactor, light water produces steam by boiling in a pressure vessel which directly pushes a turbine. Heavy water is pumped in CANDU and light water is pumped in RBMK. The maximum outlet temperature can be seen in AGR which is $6,500^{\circ} \mathrm{C}$ and the lowest outlet temperature is in RBMK which is 2,840 . An increase in temperature increases the electricity amount of a nuclear plant. A nuclear plant operation is greatly limited by the condenser's maximum pressure. The highest pressure in the coolant is seen at 2,235 psi in PWR and the minimum is seen in Magnox which is 300 psi. As refueling is an important matter of concern, time for fuel reprocessing is very sensitive. Advanced Gas Cooled Reactor (AGS) can run for 10 years without refueling whereas Magnox can run for 1 year without refueling. For PWR, BWR, CANDU, it takes a long period of time for fuel reprocessing. Graphite is used as moderator for maximum reactor including AGR, Magnox, RBMK. But in the case of PWR and BWR light water is used as a moderator of the reactor. It is observed from the Table $\mathbf{2}$ that the maximum steam cycle efficiency is seen in AGR which is $42 \%$. Magnox, PWR, BWR, CANDU, RBMK has a steam cycle efficiency of 31,32, 32, 30, and 31\%, respectively (IEE, 2005). Ascending order of steam cycle efficiency would be CANDU> RBMK $>$ Magnox $>$ PWR $>$ BWR $>$ AGR.

The steam turbine would convert thermal energy into electrical energy and thermal energy will be generated by nuclear reactor. Generated power could be varied subjected to steam transmitted into it. Again, the rest of the thermal energies produced by reactor could be utilized for fuel production, industrial process or preservation. Further, 
TABLE 2 | Technical details of different types of reactors (Bodansky, 2005; IEE, 2005; Fernández-Arias et al., 2020; U. S. Energy Information Administration, 2020; World Nuclear Association, 2021; Britiannica; Institute for Energy and Environmental Research).

\begin{tabular}{|c|c|c|c|c|c|c|c|c|}
\hline \multirow[t]{2}{*}{ Reactors } & \multirow[t]{2}{*}{ Fuel } & \multicolumn{3}{|c|}{ Coolant } & \multirow[t]{2}{*}{ Moderator } & \multirow{2}{*}{$\begin{array}{l}\text { Spent fuel } \\
\text { reprocessing }\end{array}$} & \multirow{2}{*}{$\begin{array}{l}\text { Steam cycle } \\
\text { efficiency (\%) }\end{array}$} & \multirow{2}{*}{$\begin{array}{l}\text { Main economic and safety } \\
\text { characteristics }\end{array}$} \\
\hline & & Heat extraction & $\begin{array}{l}\text { Outlet } \\
\text { temperature } \\
\left({ }^{\circ} \mathrm{C}\right)\end{array}$ & Pressure (psia) & & & & \\
\hline $\begin{array}{l}\text { Advanced Gas } \\
\text { Cooled Reactor } \\
\text { (AGR) }\end{array}$ & $\begin{array}{l}\text { Enhancement of } \\
\text { uranium dioxide to } \\
2.3 \% \text { U-235 } \\
\text { Stainless steel } \\
\text { cladding }\end{array}$ & $\begin{array}{l}\text { Steam is generated } \\
\text { in steam generator } \\
\text { by } \mathrm{CO}_{2} \text { gas which } \\
\text { is heated by the fuel }\end{array}$ & 650 & 600 & Graphite & $\begin{array}{l}\text { can be reserved deep } \\
\text { down of water for } \\
\text { over } 10 \text { years but } \\
\text { reservation can be } \\
\text { elongated if the } \\
\text { atmosphere is } \\
\text { dehydrated }\end{array}$ & 42 & $\begin{array}{l}\text { Although maintaining the } \\
\text { operational and safety advantages } \\
\text { are same as Magnox, at higher } \\
\text { temperatures and pressures, capital } \\
\text { costs are reduced and steam cycle } \\
\text { performance is increased. }\end{array}$ \\
\hline Magnox & $\begin{array}{l}\text { Uranium metal in its } \\
\text { natural state }(0.7 \% \\
\text { U235) Cladding } \\
\text { made of magnesium } \\
\text { alloy. }\end{array}$ & $\begin{array}{l}\text { Steam generator } \\
\text { raises steam with } \\
\text { the help of } \mathrm{CO}_{2} \\
\text { heated by fuel }\end{array}$ & 360 & 300 & Graphite & $\begin{array}{l}\text { Typically, within } 1 \\
\text { year, for operational } \\
\text { reasons }\end{array}$ & 31 & $\begin{array}{l}\text { The safety advantage is that the } \\
\text { coolant cannot shift phase. Due to } \\
\text { the fact that refueling occurs during } \\
\text { service, a high level of availability is } \\
\text { possible. }\end{array}$ \\
\hline $\begin{array}{l}\text { Pressurized } \\
\text { water reactor } \\
\text { (PWR) }\end{array}$ & $\begin{array}{l}\text { Uranium dioxide } \\
\text { enriched to } 3.2 \% \\
\text { U235.cladding was } \\
\text { of Zirconium alloy }\end{array}$ & $\begin{array}{l}\text { Steam generator } \\
\text { raises steam in an } \\
\text { independent circuit } \\
\text { by the pressurized } \\
\text { light water being } \\
\text { pumped to it }\end{array}$ & 317 & 2,235 & Light Water & $\begin{array}{l}\text { Can be preserved for } \\
\text { long time in deep } \\
\text { down of water } \\
\text { providing flexibility in } \\
\text { waste management }\end{array}$ & 32 & $\begin{array}{l}\text { Low construction costs as a result } \\
\text { of the design's suitability for } \\
\text { factory-built subassemblies. } \\
\text { Globally, a wealth of operational } \\
\text { knowledge has been gained. } \\
\text { Offload refueling is needed. }\end{array}$ \\
\hline $\begin{array}{l}\text { Boiling water } \\
\text { reactor (BWR) }\end{array}$ & $\begin{array}{l}\text { U-235 zirconium } \\
\text { alloy cladding and } \\
\text { uranium dioxide } \\
\text { intensified to } 2.4 \%\end{array}$ & $\begin{array}{l}\text { Pressure vessel } \\
\text { produces steam by } \\
\text { pressurized boiling } \\
\text { light water which } \\
\text { drives the turbine } \\
\text { directly }\end{array}$ & 286 & 1,050 & Light Water & As for PWR & 32 & $\begin{array}{l}\text { The cost of construction is } \\
\text { comparable to that of a PWR, but } \\
\text { the design is changed to } \\
\text { incorporate a heat exchanger, } \\
\text { though some shielding of the steam } \\
\text { circuit and turbine is needed to } \\
\text { compensate. Refueling occurs } \\
\text { during the off load state. }\end{array}$ \\
\hline CANDU & $\begin{array}{l}\text { Uranium dioxide has } \\
\text { not been enriched } \\
(0.7 \% \cup-235) \\
\text { Cladding of } \\
\text { zirconium alloy }\end{array}$ & $\begin{array}{l}\text { Heavy water raised } \\
\text { to a pressure } \\
\text { greater than that of } \\
\text { the fuel produces } \\
\text { steam via an steam } \\
\text { generator located in } \\
\text { a separate circuit. }\end{array}$ & 305 & 1,285 & Heavy water & As for PWR & 30 & $\begin{array}{l}\text { Although the operational record is } \\
\text { satisfactory, additional setups are } \\
\text { needed to supply an adequate } \\
\text { quantity of heavy water at a } \\
\text { reasonable price. }\end{array}$ \\
\hline RBMK & $\begin{array}{l}\text { Uranium dioxide } \\
\text { with a U-235 } \\
\text { enrichment of } 1.8 \%\end{array}$ & $\begin{array}{l}\text { The light water is } \\
\text { heated at a high } \\
\text { pressure and the } \\
\text { steam is used } \\
\text { directly to power } \\
\text { the turbine. }\end{array}$ & 284 & 1,000 & Graphite available & - & 31 & $\begin{array}{l}\text { On the former USSR, demonstrated } \\
\text { a satisfactory outcome. In the west, } \\
\text { it is assumed to be less } \\
\text { secure/safe. However, the literature } \\
\text { on this subject is scant, } \\
\text { necessitating additional study. }\end{array}$ \\
\hline
\end{tabular}


TABLE 3 | Examples of Renewable energy sources and nuclear in hybrid energy systems (Ruth et al., 2014).

\begin{tabular}{|c|c|c|c|}
\hline Resources & Coupling mode & Storage mode & Products \\
\hline Wind and nuclear & Electrical & Hydrogen & Electricity, hydrogen \\
\hline Biomass and nuclear & Thermal & Chemical & Electricity, biofuels \\
\hline $\begin{array}{l}\text { Nuclear, natural gas, and wind } \\
\text { energy }\end{array}$ & Thermal and electrical & Chemical & Chemical products and electricity \\
\hline $\begin{array}{l}\text { Concentrated solar power } \\
\text { (CSP) and nuclear }\end{array}$ & Thermal & Thermal & Electricity, heat \\
\hline
\end{tabular}

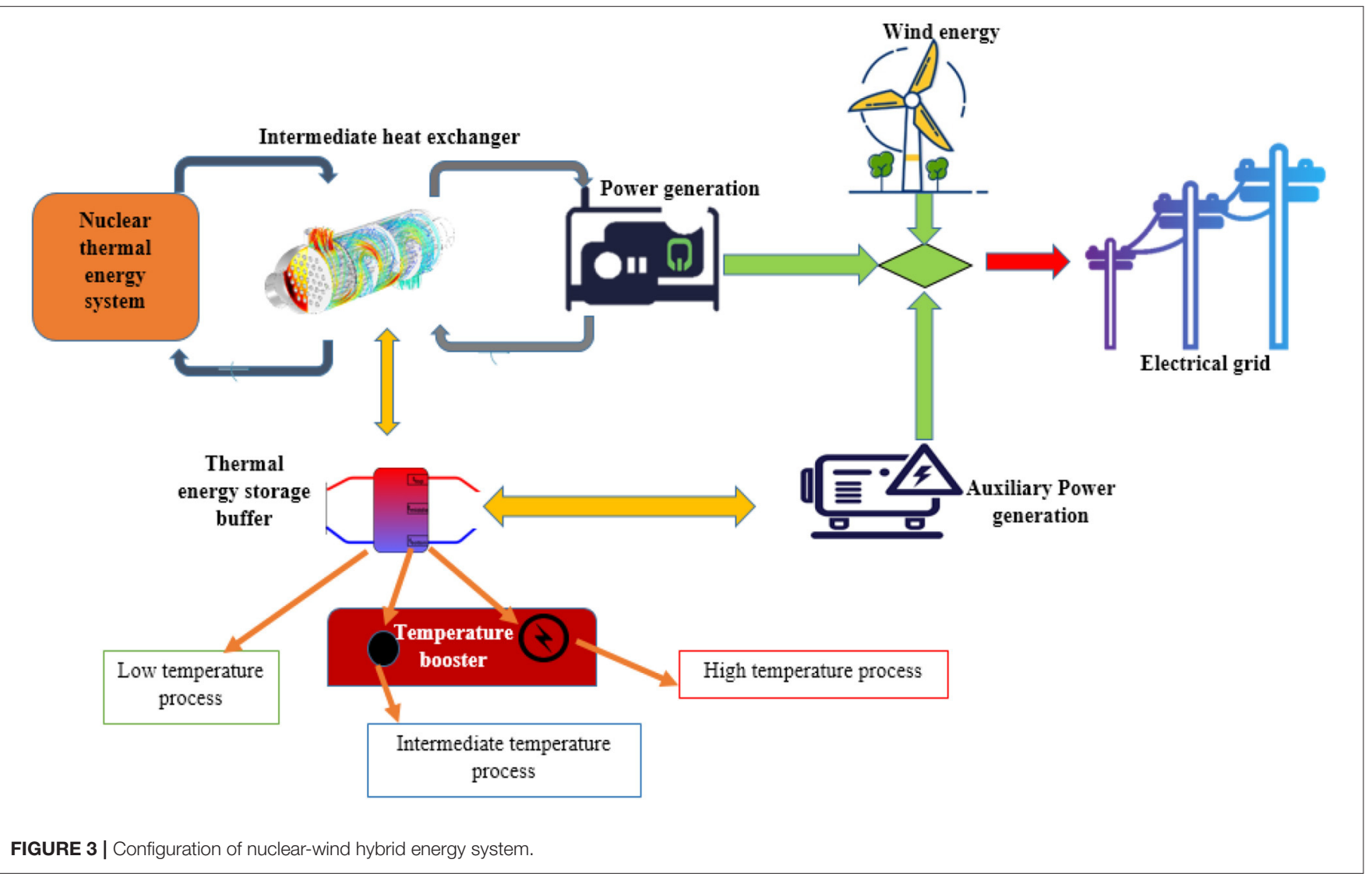

steam turbine possesses significant rotational inertia and with the help of synchronous generator it could support grid frequency constantly.

The steam turbine would convert thermal energy into electrical energy and thermal energy will be generated by a nuclear reactor. Generated power could be varied subjected to steam transmitted into it. Again, the rest of the thermal energies produced by the reactor could be utilized for fuel production, industrial process, or preservation. Further, the steam turbine possesses significant rotational inertia and with the help of a synchronous generator, it could support grid frequency constantly (Bodansky, 2005; Fernández-Arias et al., 2020).

Renewable energy sources like photovoltaic solar panels, wind, etc. can generate energy in form of heat and power without greenhouse gas emissions. Table 3 demonstrates some examples of renewable energy sources with nuclear plants in N-R-HES variable renewable technologies. The study reveals that, if the wind energy penetration outstrips about 30\% of total power generation, the internal rate of return of the hybrid energy system would be more than conventional systems (Ruth et al., 2014). Moreover, heat and electricity from these sources could also be used by industrial processes, fuel production or could be stored.

When coupled with a nuclear and renewable energy source as a hybrid system such as in Figure 3, the industrial processes would obtain heat and power from the renewable energy source(s) and reactor(s). Therefore, the system would use the energy to harvest high-value products or fuels. Heat can also be supplied by reserved thermal energy or harnessed from different energy sources when continuous action of the industrial process is required.

N-R-HES systems differ from combined heat and energy generation systems in that the objective is not only to generate 
TABLE 4 | Temperature ranges corresponding to industrial process reactions mechanism with potential heat sources (Ruth et al., 2014).

\begin{tabular}{|c|c|c|c|}
\hline Mechanism & Temperature range & Example & Potential heat sources \\
\hline $\begin{array}{l}\text { Reactions at elevated temperatures } \\
\text { in the gas phase; metal refining; } \\
\text { heterogeneous gas-solid reactions; }\end{array}$ & $\operatorname{High}\left(1,000-1,500^{\circ} \mathrm{C}\right)$ & $\begin{array}{l}\text { Gasification of coal; steel production; } \\
\text { manufacture of cement and glass; steam } \\
\text { superheating }\end{array}$ & $\begin{array}{l}\text { Coal combustion or natural gas; high } \\
\text { temperature plasma generation; electric arc } \\
\text { generation; CSP }\end{array}$ \\
\hline $\begin{array}{l}\text { Scission of multiple bonds; } \\
\text { hydrogen abstraction reactions }\end{array}$ & $\begin{array}{l}\text { Intermediate/moderate } \\
\left(700-950^{\circ} \mathrm{C}\right)\end{array}$ & $\begin{array}{l}\text { Steam methane reforming; natural gas } \\
\text { liquids cracking to ethylene and } \\
\text { propylene; biomass gasification and high } \\
\text { temperature steam electrolysis }\end{array}$ & $\begin{array}{l}\text { Gas-cooled nuclear reactor with high } \\
\text { temperature. }\end{array}$ \\
\hline $\begin{array}{l}\text { Devolatilization endothermic } \\
\text { reactions, pyrolysis of organic } \\
\text { compounds }\end{array}$ & $\begin{array}{l}\text { Intermediate/lower } \\
\left(350-600^{\circ} \mathrm{C}\right)\end{array}$ & $\begin{array}{l}\text { Cracking; biomass pyrolysis; distillation; } \\
\text { in-situ retorting of oil shale; and reforming } \\
\text { of petroleum-heavy end products }\end{array}$ & $\begin{array}{l}\text { Biomass combustion; Molten salt reactor; } \\
\text { nuclear reactor with liquid metal cooling; } \\
\text { biomass combustion }\end{array}$ \\
\hline $\begin{array}{l}\text { Generation of saturated steam; } \\
\text { sensible heating }\end{array}$ & Low $\left(50-320^{\circ} \mathrm{C}\right)$ & $\begin{array}{l}\text { Numerous chemical processes; } \\
\text { torrefaction of biomass; desalination of } \\
\text { water; district heating }\end{array}$ & $\begin{array}{l}\text { Geothermal sources and light water nuclear } \\
\text { reactors }\end{array}$ \\
\hline
\end{tabular}

heat and power for use in regional industrial plants but also to transmit as much low carbon energy as possible to industrial processes. Many industrial processes demanding large thermal inputs could be well-suited for coupling in a N-R-HES. Various industrial processes with suitable temperature range and the potential heat source are shown in Table 4 (Ruth et al., 2014). It can be seen that mechanisms like high-temperature gas reactions, metal refining happens in high-temperature environments and heat came here by an electric arc, coal combustion, plasma generation, etc. Processes like sensible heating and saturated heat production occur in relatively low temperatures. Chemical processes and torrefaction occur in this temperature range. Biomass pyrolysis, petroleum reforming transpires in organic compound pyrolysis and endothermic reactions also occur in this temperature range of $350-600^{\circ} \mathrm{C}$.

Storage could be electrical, thermal, or chemical. Electrical storage consists of flywheels and batteries. Thermal storage options include solid forms like firebrick and liquid forms like molten salt. Chemical storage includes thermally assisted electrolysis similar to hydrogen production. Heat withdrawn from the reservoir could be utilized directly in the industrial process or to produce power.

Power generators are the heat exchangers that transform water into steam using heat originated in a reactor. The heat produced in the reactor core is supplied to the secondary side. The important function of a steam generator is to maintain separation between reactor coolants. However, it may be polluted with radioactive products and by the environment.

\section{CONFIGURATIONS AND SIZING OF N-R-HES}

\section{Configurations of Nuclear-Renewable Hybrid Technology}

In terms of nuclear energy generation, the majority of the plant configuration includes a reactor system and a steam system where the reactor acts as primary and steam as a secondary system. These configurations are used to keep radioactive atoms and materials in the primary system. However, in the primary reactor system, the reactor coolant is pressurized inside the reactor vessel without the process of boiling. On the other hand, in the steam generators, the generated steam is utilized to drive a turbine-generator set that can be used to generate power. While the energy is generated through renewable sources, the system usually includes a photovoltaic system, batteries, diesel generators, wind turbines (Senjyu et al., 2007). In addition, there are other renewable sources of energy that are used in hybrid nuclear energy systems, such as hydroelectric, biomass, marine technologies, and geothermal. All these sources of renewable energy have numerous economic, environmental, and geographic considerations that are significant to make the hybrid nuclear-renewable energy system more practically implementable. Therefore, configurations of nuclear-renewable hybrid energy technology solely depend on the economic, environmental, and geographical locations of an area (Suman, 2018). However, the generation of power capacity of photovoltaic cells (solar) and wind turbines is variable. As a consequence, due to the higher level of penetration of these energies of renewables, it is required to use a combined system of hybrid nuclear renewable sources that can meet up the required demand for electricity. Although the system of hybrid nuclear renewable sources of energy configurations increases the overall cost when compared to the traditional system, they decrease greenhouse emissions of harmful gases. The hybrid nuclear-renewable energy system configurations can utilize the energy resources more effectively so that the overall lifetime of these sources of energy is increased.

Different forms of renewables are added with nuclear sources of energy to build the general configurations of nuclearrenewable hybrid energy systems (Keller, 2011). For example, nuclear sources of energy (radiative materials) can be added with renewable sources such as biomass, wind, natural gas, geothermal, and solar power, where the prospective outcome of energy are electricity, heat, biofuels, and chemical products. In order to couple these sources of energy, electrical, thermal, and a combination of electrical-thermal methods are used where hydrogen, thermal, and chemical forms of systems for storage are commonly used. 
For a nuclear-solar hybrid energy system, a nuclear type reactor is used to compress the flowing fluid that is utilized to expand turbines for power generation. These types of mechanisms can be applied to the reactor as well as air pressurizing plants where rotating compressors, turbines are used (Keller, 2011). In these configurations, a heat exchanger is combined that helps to extract lower graded heat energy from the flowing fluid. The extracted heat is transferred to the equipment used for moisture removal that is usually located at the downside of the hybrid system. However, to develop the efficiency of a nuclear-renewable hybrid system, a heat exchanger of regenerative type is added that can previously heat up the flowing fluid before entering into the nuclear reactor that extracts lower graded heat of the fluids. Hence, the overall efficiency of the system is increased by extracting the lower graded heat from the flowing fluid that usually discharges from rotating turbines.

Another possible configuration of N-R-HES includes a solar thermal system with a nuclear reactor where the heat generated from solar rays is utilized to heat nuclear steam to produce electricity. This configuration of a concentrated solar thermal system can increase the power generation capacity from a nuclear reactor plant to $\sim 37.5 \%$. On the contrary, electricity conversion capacity through the use of the heat of solar rays is increased around $56.2 \%$ that is close to the effectiveness of traditional combined cycle plants of the gas turbines (Tesfa et al., 2013; Borissova and Popov, 2015).

Another significant configuration involves geothermal energy sources with a nuclear reactor where a pumping mechanism is attached to inject underground fluid from the reservoir by using an injection mechanism in soil bedrock. This can further be sucked using a bore that is coupled to operate a traditional steam turbine plant for the generation of power. Due to the injection of fluid into soil bedrock, there occurs a transfer of heat to the fluid that is minimized through the use of a nuclear reactor that is placed on the bores of the hot rock region (Chen et al., 2001).

Wind energy is a significant source of renewable energy that has the potential to integrate with a hybrid system of reactorbiomass to generate hydrogen $\left(\mathrm{H}_{2}\right)$ (Papaioannou et al., 2014). In this configuration, a nuclear reactor generates thermal energy continuously with a full capacity. These reactors have the capacity to switch the generated thermal energy or heat to generate steam for producing electricity as well as biomass unit. Therefore, the hybrid energy system of wind-nuclear reactor operates according to meet up the higher demand for electricity, while the hydrogen generation unit requires electrical energy and operate on the excess power produced during the time of performance of peak farm of wind energy. For example, consider the operation of a typical light water nuclear-wind energy system with a closedloop cycle. In this system, the nuclear system provides its heat into the main coolant such as water, molten metal mixture, helium. After that, the coolant transfers the absorbed heat to a secondary medium depending on the output temperature of the main coolant, characteristics of the coupling process, and power-producing cycle. However, in this configuration, the Brayton-Rankine cycles are used when high-temperature (620$1,650^{\circ} \mathrm{C}$ ) heat is available with up to $60 \%$ efficiency (Pioro, 2013). Moreover, the heat from the main coolant to the secondary level generally passes through the thermal heat exchanger that combines the nuclear system and the power generation system. The secondary coolant is dynamically distributed among the thermal storage buffer and power generation system where the power generation block, auxiliary power unit, and wind energy supplies energy to the power grid. However, to control this hybrid configuration, an advance remote flow monitoring system, pumps, control valves, and a new heat-exchanger can be used.

\section{Arrangements and Sizing of Systems}

The arrangement and sizing of the hybrid renewable system is the basic level of the optimization as well as the design process. In general, configurations and sizing can be done by using four different methods as probabilistic, iterative, analytical, and model through a hybrid system (Luna-Rubio et al., 2012).

The probabilistic method is the easiest method for the configurations and sizing of the hybrid system of renewable sources. However, the estimated results are not always appropriate to find the exact configurations of the system design of hybrid renewable sources. To obtain the best outcome for sizing and configurations of individual components, either a single or two system indicators of performance are increased It is obtained that the configurations of the systems of hybrid renewable sources (photovoltaic-wind energy systems with nuclear reactor) can be performed using the density function based on probability by following the technique of convolution (Mahmoudi et al., 2008).

On the other hand, in the case of the analytical method, the sizing and configurations are done based on the computational models that provide the description of the system as the feasibility of techno-economic analysis. By following these guidelines, the sizing and configurations of the hybrid renewable energy systems are determined as well as the performance is identified. The significant advantage of this process is that it helps the designer by providing all the information of the simulation for the performance of the hybrid renewable energy system. However, the disadvantage is that it needs weather data for the process of optimization. Although HOMER, HOGA, HYBRID-2 can be used to solve this type of problem (Luna-Rubio et al., 2012).

Another important process is known as the recursive or iterative method that can define the sizing and configurations of a system of hybrid nuclear renewable energy sources. It designs the most effective configurations depending on the characteristics of the design. For example, the most effective configurations (Ashok, 2007; Luna-Rubio et al., 2012) of hybrid renewable energy systems were obtained by reducing the life cycle cost to a minimum value through the process of the iterative method. In this method, the algorithm of the Quasi-Newton process is employed to find the optimal system configurations. In the iterative process, by selecting the model, a number of commercial components that are available, and calculating the storage system, the configurations of the hybrid renewable energy system are determined. This method can be applied in off-grid rural areas as well as grid-connected areas for the optimal sizing and configurations of the hybrid nuclear-renewable energy system (Ashok, 2007; Luna-Rubio et al., 2012). 
The last method of identifying the size and configuration of the nuclear renewable hybrid systems is the hybrid models. This process is suitable due to the multidimensional nature of optimal systems of hybrid nuclear renewable energies. This method can solve this type of multidimensional problem based on different heuristic processes such as PSO, genetic algorithm, and neural network Many times, two or three methods of optimization are used together to provide the most efficient and effective configuration as well as sizing of the hybrid system of nuclear renewable energy.

\section{ASPECT OF INTERCONNECTIONS}

Six interconnections including thermal, mechanical, chemical, hydrogen, electricity, and information interconnection with their basic requirements are shown in Figure 4. It shows that the efficiency of the hybrid system depends on the smart control system, monitoring system, and heat management system via advanced technologies. However, there are significant technical problems that include interconnections as well as a few additional system problems due to the implementation of the N-RHES system. Figure 4 depicts some of the more interesting interconnection adaptations (Suman, 2018) and the explanation of each interconnection is described in detail as follows.

\section{Thermal Interconnections}

There are several types of sources from which heat can be generated, for instance, biomass, solar system, and geothermal. Further, in the industrial sector, reducing or releasing heat from a nuclear reactor by applying a cooling method is a common practice. The combined power generation and distribution heating system currently uses nuclear heat in Europe (Barbir, 2012). Besides, this concept can be applied in coal type and combined cycle power plants.

The heart of N-R-HES is thermal interconnection which is complex and includes some requirements such as heat availability, time response rate, and high-capacity thermal reservoir. Industries can use thermal energy in many ways, for example, a lower temperature is used for the extraction of hot water during petroleum production at the industrial level. Figure 5 illustrates the mechanism used in the industrial processes with temperature ranges, and also the potential thermal sources (Ruth et al., 2014). The extraction of heavy crude oil and sand bitumen is done with a steam-assisted gravity drainage method at $300-350^{\circ} \mathrm{C}$ steam (Oyeneyin et al., 2012). The crude oil conversion process may use a moderate system at a temperature range of $350-500^{\circ} \mathrm{C}$. However, the production of biofuels can use heat energy for several purposes. Biomass can be converted into a bio-crude through an ideal condition of pyrolysis and biomass decomposition at a temperature range of $350-500^{\circ} \mathrm{C}$ (Trippe et al., 2010). Lower temperature processed heat is utilized with a feedstock drying system and chemical processes use higher temperatures. Heat can be used to reform the natural gas, gasification of biomass, and coal in a temperature range of $850,800-1,000$, and $1,000-1,200^{\circ} \mathrm{C}$, respectively. All these processes can be incorporated with N-RHES. Therefore, the heat source is one of the main factors for thermal interconnection.

\section{Electricity Interconnection}

In the existing market, the interconnection of electricity is one of the key considerations. During the designing and operating process of a hybrid system, this parameter must be considered for optimum output (U. S. Department of Energy, 2015). Internally, the use of electrical energy not only depends on the current requirements of the market but also on all the ramps of electrical equipment. A short- and long-term strategy will be needed for adjusting the use of electricity in the hybrid energy system. In the particular situation of economically feasible energy supply, the excess of electricity can also be kept stored utilizing batteries or pumped storage technologies. In the case of financing, capital investment depends on the return investment (Boarin et al., 2012). The public utility commission establishes suitable retail power rates as well as ensures a secured market. Cochran et al. (2012) claimed that electrical markets may not always allocate adequate value to systems that offer grid stability in their present form.

\section{Chemical Interconnection}

Chemical interconnection plays a vital role in the hybrid system. A nuclear plant can provide syngas, high purity hydrogen, and other active chemicals to generate electricity. In biomass gasification, hydrogen and syngas are necessary for the generation of electricity and chemical substances make the most promising contribution to minimizing the requirement for fossil fuels such as coal and oil considerably. Figure 6 illustrates the chemical reaction of the production of synthetic fuels (van de Loosdrecht and Niemantsverdriet, 2013). Biomass, natural gas, coal and any hydrocarbon feedstock can produce syngas by reacting with steam and $\mathrm{O}_{2}$. Syngas is a mixture of $\mathrm{CO}, \mathrm{CO}_{2}$, and $\mathrm{H}_{2}$ and its composition is highly endothermic and involves very high temperature.

Catalysis and refinement processes for diesel production by Fischer-Tropsch is an alternative route to produce energy with synthetic fuels (Figure 6). Several power companies and catalyst industries have advanced this technology. In Fischer-Tropsch Synthesis (FTS), syngas is transformed into hydrocarbons, the basis of which is jet fuel, petrol, diesel and chemicals such as olefins and waxes. It is an integral part of the gas-to-liquid (GTL) and coal-to-liquid (CTL) plants.

Equations (1)-(3) represent chemical reactions which are exothermic reactions, and therefore, heat management is a crucial part of reactor design. Those reactions are possible under suitable temperature and pressure ranges from 200 to $305^{\circ} \mathrm{C}$ and $20-50$ bar, respectively. Equation (4) (Christiansen and Rostrup-Nielsen, 2011) represents the water gas shift reaction which produces high purified hydrogen. Also, methanol can be produced from syngas and used as a fuel (van de Loosdrecht and Niemantsverdriet, 2013). Applications of the syngas include (Walker) steam for power generation driven by turbines, methanol used to produce plastics, pharmaceutical resins, and fuel, carbon monoxide for feedstock, and fuels in 
- Heat from nuclear reactor is key focus point

- High capacity heat reservoir is required

- Need effective Research and development sector

- Design a better heat exchanger is required
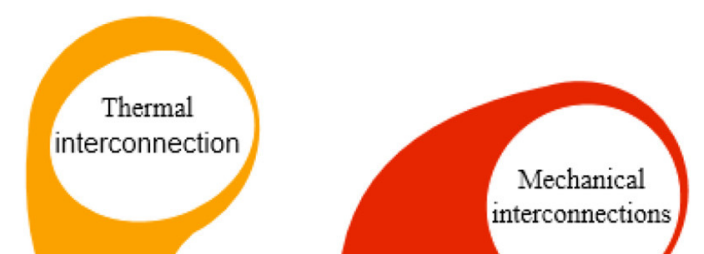

- Custom design of mechanical coupling is prerequisite

- Need advance gear ratio and a electric or gas motor

- Advance power electronics are compulsory

- Advance interconnected sensing technology and informatics system is essential

- Supply-chain management tools must be developed

- Need advance tracking and control system

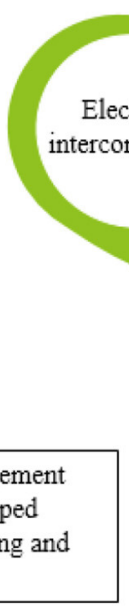

Electricity

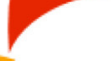

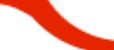

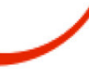

FIGURE 4 | Six interconnections pathway for nuclear-renewable hybrid system.

\begin{tabular}{|c|c|c|c|}
\hline Low & $\begin{array}{c}\text { Lower or } \\
\text { intermediate }\end{array}$ & $\begin{array}{l}\text { Eligher or } \\
\text { intermediate }\end{array}$ & High \\
\hline $50-320^{\circ} \mathrm{C}$ & $350-600^{\circ} \mathrm{C}$ & $700-950^{\circ} \mathrm{C}$ & $1000-1500^{\circ} \mathrm{C}$ \\
\hline $\begin{array}{c}\text { Mechanism } \\
\text { Saturated steam production; } \\
\text { sensible heating } \\
\text { Many chemical processes; } \\
\text { biomass torrefaction; water } \\
\text { desalination; district heating }\end{array}$ & $\begin{array}{l}\text { Mechanism } \\
\text { Devolatilization endothermic } \\
\text { reactions, organic compound } \\
\text { pyrolysis }\end{array}$ & $\begin{array}{l}\text { Mechanism } \\
\text { Multi-bond scissioning; } \\
\text { hydrogen } \\
\text { abstraction reactions }\end{array}$ & $\begin{array}{l}\text { Mechanism } \\
\text { Metal refining; } \\
\text { heterogeneous gas- } \\
\text { solid reactions; high } \\
\text { temperature } \\
\text { gas phase reactions }\end{array}$ \\
\hline Potential Heat Source & Potential Heat Source & Potential Heat Source & Potential Heat Source \\
\hline $\begin{array}{c}\text { Light water nuclear } \\
\text { reactors; geothermal } \\
\text { sources }\end{array}$ & $\begin{array}{l}\text { Molten salt reactor; liquid } \\
\text { metal cooled } \\
\text { nuclear reactor; biomass } \\
\text { combustion }\end{array}$ & $\begin{array}{l}\text { High temperature gas-cooled } \\
\text { nuclear reactor }\end{array}$ & $\begin{array}{l}\text { Combustion of natural gas } \\
\text { or coal; electric } \\
\text { arc; high temperature } \\
\text { plasma generation; } \\
\text { concentrating solar power }\end{array}$ \\
\hline
\end{tabular}

FIGURE 5 | Potential heat sources and mechanisms with temperature ranges (Trippe et al., 2010; Oyeneyin et al., 2012; Ruth et al., 2014). 


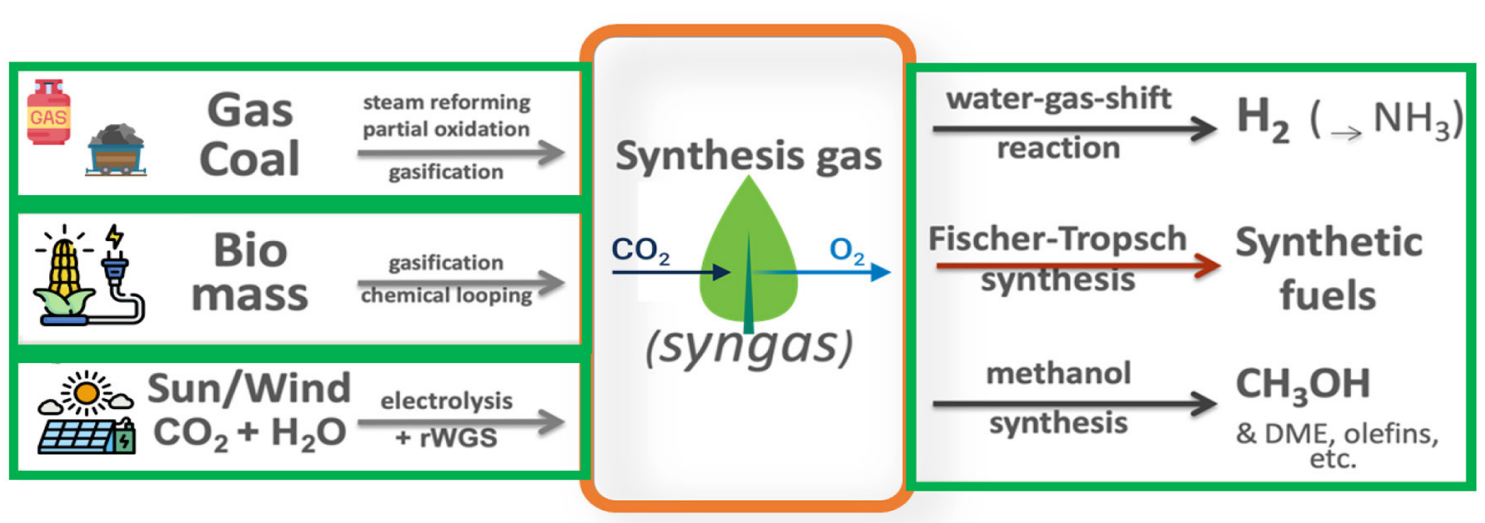

FIGURE 6 | Chemical reaction of synthetic fuel production (Christiansen and Rostrup-Nielsen, 2011).

the chemical industry. As a result, auxiliary power generation based on preserved chemical electricity could aid in the smooth transition of nuclear progressions.

$$
\begin{array}{r}
\mathrm{nCO}+(2 \mathrm{n}+1) \mathrm{H}_{2} \rightarrow \mathrm{CnH}_{2 \mathrm{n}}+2+\mathrm{nH}_{2} \mathrm{O} \\
\mathrm{nCO}+2 \mathrm{nH}_{2} \rightarrow \mathrm{CnH}_{2 \mathrm{n}}+\mathrm{nH}_{2} \mathrm{O} \\
\mathrm{nCO}+2 \mathrm{nH}_{2} \rightarrow \mathrm{CnH}_{2 \mathrm{n}}+1 \mathrm{OH}+(\mathrm{n}-1) \mathrm{H}_{2} \mathrm{O} \\
\mathrm{CO}+\mathrm{H}-{ }_{2} \mathrm{O} \rightleftharpoons \mathrm{CO}_{2}+\mathrm{H}_{2}--41 \mathrm{~kJ} / \mathrm{mol}
\end{array}
$$

\section{Mechanical Interconnection}

A turbine is a machine that turns rotational energy into usable work or electricity from a fluid collected by a rotor system such as a compressor or pump. This rotational energy can be used in a hybrid system by direct coupling using a flywheel. A flywheel is a mechanical device that stores energy as the kinetic energy of motion in a rotating mass (Breeze, 2018). This is beneficial in specific industry processes or handles huge electrical load fluctuations rapidly if the power converter is also linked to the flywheel. In this case of coupling, there may be energy loss, but to minimize the loss, the magnetic bearing can be used through a vacuum space. However, researchers should be concerned about the gear meshing and gear ratio during coupling as the number of research in this sector is limited.

This schematic diagram shown in Figure 7 demonstrates the mechanical connection connected with the turbo-expander for more efficiency. The turbo expander is used in a pressure reducing station rather than an expansion valve and offers a way of capturing the energy loss in natural gas plants and refineries. The gas is cooled through the Joule-Thomson effect while using a turbo expander. New turboexpanders are efficient for managing the loss of temperature in certain circumstances. A turbo-expander can connect a second power generator like a fuel cell or a traditional fuel combustion power source. This secondary source creates waste heat which is used to balance the turbo expander's cooling effect. This coupling between the turboexpander and the secondary generator enhances the system's net efficiency However, Mechanical drives are usually costlier than electric motors. In particular cases like a directdrive emergency backup of pumps or compressors, mechanical interconnections are extremely helpful (Ruth et al., 2014).

\section{Hydrogen Interconnection}

In nuclear renewable hybrid energy systems, hydrogen can also be generated mainly in two ways: (a) thermochemical cycle (T-C) and (b) electrolysis. Thermochemical cycles generate hydrogen by a series of chemical reactions using high-temperature heat of about $500-2,000^{\circ} \mathrm{C}$, which extracts hydrogen and oxygen from water within a closed-loop (Office of Energy Efficiency and Renewable Energy). There are also numerous sorts of thermochemical cycles.

The Sulfur-iodine cycle is a well-known method for producing hydrogen in the S-I thermochemical cycle. This cycle has the advantage of all chemicals being used in liquid or gaseous stages because the chemical cycle can maintain a perfect balance between the elements in a chemical reaction. However, a high temperature is required $\left(500-800^{\circ} \mathrm{C}\right)$ to run this cycle, which is the main drawback. Nevertheless, this high heat can be obtained from nuclear and solar systems. The $\mathrm{Cu}-\mathrm{Cl}$ cycle has a low-temperature demand of about $<600^{\circ} \mathrm{C}$. Hydrogen can be produced in the first step of this cycle with the help of $\mathrm{HCl}$ as the following Equation (5). As a result of its lower temperature requirement, individual reactors can be used to produce hydrogen from nuclear power plants.

$$
2 \mathrm{CuCl}_{(\mathrm{aq})}+2 \mathrm{HCl}_{(\mathrm{aq})} \rightarrow 2 \mathrm{CuCl}_{2(\mathrm{aq})}+\mathrm{H}_{2(\mathrm{~g})}
$$

The Iron-Oxide cycle is one of the attractive thermochemical cycles, which works with a couple of redox expressions as Equations (6) and (7). It would be advantageous due to its lower chemical complexity and low cost. However, the chemical conversion rates into hydrogen can be affected by a mild temperature drop. For this reason, it can be less efficient, which is the main drawback. Further, the $\mathrm{Zn}-\mathrm{ZnO}$ cycle is similar to the Iron-Oxide cycle employing the solar thermochemical cycle. It can be used to produce hydrogen through an endothermic 


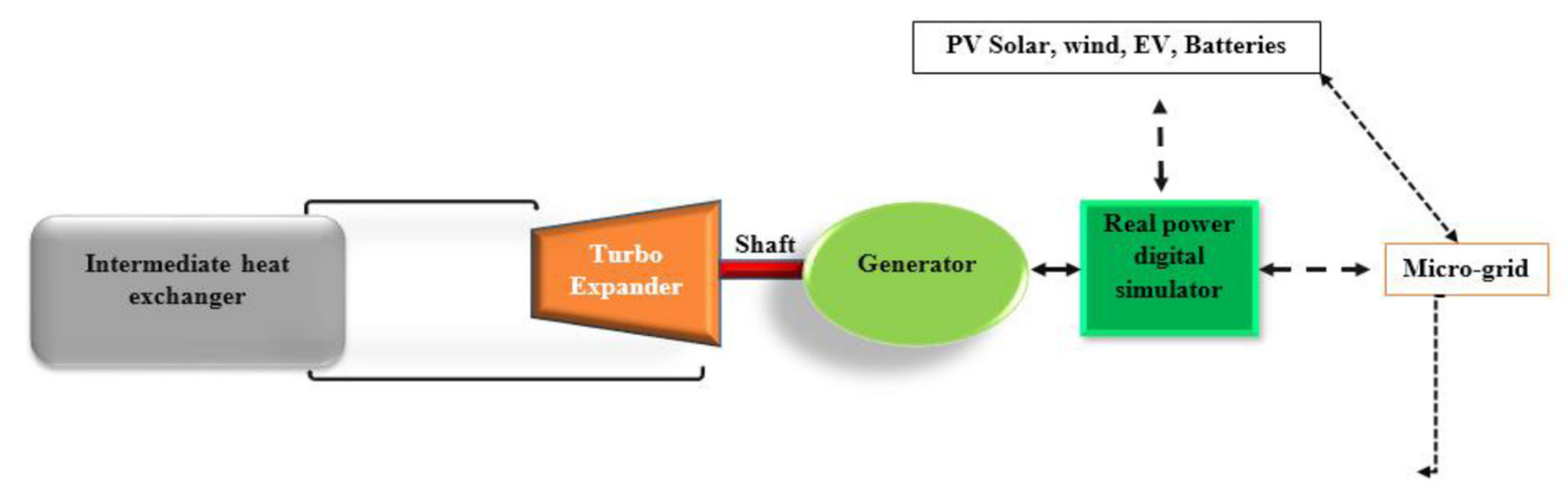

FIGURE 7 | Schematic of mechanical connection.

reaction. Nonetheless, a high amount of energy is needed (310$350 \mathrm{~kJ} / \mathrm{mole}$ ) to dissociate the $\mathrm{ZnO}$.

$$
\begin{array}{r}
\mathrm{Fe}_{3} \mathrm{O}_{4} \rightarrow 3 \mathrm{FeO}+\frac{1}{2} \mathrm{O}_{2} \\
3 \mathrm{FeO}+\mathrm{H}_{2} \mathrm{O} \rightarrow \mathrm{Fe}_{3} \mathrm{O}_{4}+\mathrm{H}_{2}
\end{array}
$$

Further, electrolysis has become a useful approach to produce hydrogen from a renewable source, by which water is divided into oxygen and hydrogen through electrical energy. This reaction occurs in a unit named electrolyzer and hydrogen can be produced from this unit (Office of Energy Efficiency and Renewable Energy). The device is divided into two parts: The High-Temperature Electrolyzer (HTE) and the LowTemperature Electrolyzer (LTE). The heat and electricity are mutually utilized by the nuclear reactor by HTE and LTE, which only use electricity.

\section{Information Interconnection}

A data measuring, data collection, and distribution system concluded that more interactive and optimized mediums are required to run system monitoring. Moreover, business and product planning information refines and adjusts the hybrid system's overall energy system plan. However, the production plan should be based on the weather forecast, and supply chain management may be advanced to recover the product condemnation. Supply chain management should be specifically designed to support installations that achieve rapid electricity grid dynamics (Ruth et al., 2014).

Another relevant term in information interconnection is the online-monitoring (OLM) system as it describes the various types of methods or techniques and processes, including the technology of noise investigation, the sensors' life cycle of a nuclear power plant, process, and data collection from a plant during plant operating time. As a result, plants can concentrate on maintenance activities where most necessary, trips to plants may be reduced, schedules may be optimized for maintenance, and the plant's outages may be reduced. To contribute to improve plant maintenance, OLM systems should be incorporated into the design of the next generation of reactors through automated measuring, condition monitoring, and diagnostics (Hashemian, 2011).

\section{PLANT LICENSING AND PERMITTING Policies and Regulations in USA}

In the US civilization or the countries that follow US licensing rules, are regulated by Nuclear Regulatory Commission (NRC). The goal of NRC is to protect public health and ensure safety regarding nuclear radiation and also from other radiological sources. The NRC licensing practice is classified into law in Title 10, "U.S. Nuclear Regulatory Commission Regulations," of the Code of Federal Regulation. Either Part 50 or Part 52 is used for licensing of nuclear power plants under "Domestic licensing of production and utilization facilities, of Title 10." Licensing is a very structured process. Generally, the review, guidance, and acceptability of the plant are provided in NUREG0800 (US Nuclear Regulatory Commission Regulation). The whole system should be defined so precisely that the nonnuclear systems can not affect the operation and safety of the nuclear subsystems. NRC has provided some specific guidelines for calculating the exclusion boundary of a plant. The guidelines suggest that the boundary should be 0.5 miles in radius. However, based on design and geographic conditions, the boundary can be larger or smaller in size. If the chemical facility is placed outside the boundary, the area is called a low-population zone. In case of any problem or accident, personnel living in the low-population zone must be able to evacuate the area immediately. Further, the chemical facility must have a rapid shut down facility.

In a case reactor, the reactor interacts with the external world with two interfaces which include cooling water intake from the heat sink and the electrical connection to the grid (Bragg-Sitton et al., 2016). Generally, NRC permits the operation of a nuclear reactor for 15 years for an independent and specific site. When a design is proposed, NRC may or may not permit the design based on specific rulemaking. Further, NRC publishes the rules in Federal Register for public comments. After that, based on the comments NRC may 
make changes in the rule and again published it in Federal Register, which then becomes an Appendix. Further, NRC can make changes in the rules in very limited and strict circumstances (USNRC).

\section{Policies and Regulations in Russia}

The importance of nuclear safety and security issue is now the primary concern of the global nuclear governance system. Nuclear safety rules and regulations are illustrated clearly and neatly in the Convention on Nuclear Safety (CNS) (International Atomic Energy Agency). If the CNS once authorizes any country, it is legally bound to abide by all the rules set by the CNS, and already 50 states have enlisted themselves in the CNS voluntarily. Some additional provisions and requisites on secure storage and transport of nuclear pollutants are elucidated in the Joint Convention on the Safety of Spent Fuel Management and on the Safety of Radioactive Waste Management (joint convention) (International Atomic Energy Agency). International nuclear security rules, emphasizing prohibiting the stealing of nuclear ingredients, insider threats and nuclear violence, are clearly narrated in the Convention on the Physical Protection of Nuclear Material (CPPNM), its 2005 amendment, and the International Convention on the Suppression of Acts of Nuclear Terrorism (ICSANT) (International Atomic Energy Agency; International Atomic Energy Agency; United Nation, 2005). The international nuclear security conventions do not require obligatory evaluations or reviews; rather, they depend on voluntary enforcement. All the international providers, including Russia, the USA, France, China, Japan, and South Korea, are the signatory to all the nuclear safety, and security conventions, and they play a significant role in inspiring its client to follow all the rules. It is not adequate for the other countries to follow Russia's record of maintaining international rules. The purchaser countries do not have to follow any agreement or convention beyond the NPT except India if the purchaser countries want to enroll the Russian framework agreements.

Nevertheless, they must retain enormous protection agreements with the IAEA. However, an approach to acknowledge or ratify any additional agreements is called officially by few other providers. Urge for abiding by IAEA safety standards and obedience to "accepted international safety conventions" are narrated evidently in NSG customs, but only mainly there is an indication for the CNS in the context of ENR transfers (Article 6, a, vi) (Borowy and Salameh, 1996). There is a guideline which is related to nuclear security is stated only under Article 13, and the statement is that "Extensive compliance with the respective international apparatus, including the assemblage on the Physical Safeguard of Nuclear components as well as the implementation of INFCIRC/225 as amended, should be publicized regularly." Since the states possessing nuclear weapons are not interested in imposing further nuclear disarmament on their nuclear weapons, additional commitments are almost politically difficult to impose on those states which have no nuclear weapons as yet. Providers turned down when calls were told to establish mandatorily for the CNS (Katsigiannis et al., 2010). Except for the amendment to the CPPNM, only three countries Bangladesh, India, and Turkey, which are the main clients of Russia, have agreed to follow all the customs of the Joint Convention and Belarus. Though Iran and Egypt are convinced to sign few conventions, they have not admitted yet to follow any convention described above. Other Countries which are bound to follow a framework agreement with Russia have versatile records. Uzbekistan is not a member of CNS because it has not yet enlisted itself in CNS. Sudan has not agreed to follow any of the conventions. New counties, such as Nigeria and Ghana, have been showing immense enthusiasm in joining and following all the conventions of the IAEA-led Integrated Nuclear Infrastructure Review, which assists in evaluating the framework resulting in the start of the legal nuclear energy program.

\section{European Policies for Nuclear Power Plant}

The primary liability for the management and security of nuclear facilities is with national authorities, and this independence is strongly reserved against European Union (EU) intrusion. A world organization nuclear safety directive in 2009 emphasized the elemental principle of national responsibility for nuclear safety (Nuclear Power in European Union, 2021). A modification to the protection directive approved by the alignment in July 2014 introduces a high-level EU-wide nuclear safety objective that aims to limit the results of an attainable nuclear accident additional as address the protection of the complete lifecycle of the atomic establishment (siting, pattern, planning, authorization, operation, and deactivation of nuclear plants), in conjunction with on-the-scene emergency readiness and response. It also introduces a group of rules to support the independence of national nuclear safety regulators, with a replacement inspection scheme. There are two corporations of regulators that are significant. They are WENRA and ENSREG, which became more critical once the Fukushima accident (Nuclear Power in European Union, 2021).

The Western European Nuclear Regulators' Association (WENRA) may well be a network of chief regulators of EU countries with atomic energy plants and Swiss Confederation, membership from 17 countries. Various interested European countries have observer standing. It had been designed in 1999 and has contended a severe role in coordinating safety standards across Europe in conjunction with vital involvement in Europe. It is seeking increasing engagement with regulators inland, Ukraine, and Russia.

In Europe, six national bureaus from the EU have united to form a band to assist European countries with radioactive material management.

The European Nuclear Safety Regulators cluster (ENSREG) is a freelance, authoritative skilled body created in 2007 by the EU Commission to revive the EU nuclear safety notice passed in 2009. It includes senior officers from the national nuclear safety, material safety, and radiation protection restrictive authorities from all EU member states and representatives of the EU Commission. It can help determine the conditions for continuous improvement and reach a typical understanding among nuclear safety and material management 
areas. It continues to form recommendations to and via the EU Commission.

\section{Nuclear Safety and Standard Policies for Bangladesh}

The government of Bangladesh supported the National Nuclear Action found out (BNPAP) to meet the functions mentioned above for the early implementation of the atomic energy project in 2000. A cabinet committee, presided by the authorization of the govt, has to turn the project. It takes all scheme selections supported by the information and analyses created offered to it. This has also expedited establishing correct linkages between the macro and microscopic level turning out with. Recently, new safety concerns, standardization, codes, and guides are created to line up the atomic energy plant successfully. The maximal size of any station to be unified into a grid has to be compelled to be concerning $10 \%$ of its peak demand. An atomic energy plant ideally wants concerning 6 years for implementation. Accounting for this and the expansion of demand within the meantime, a 600-1,000 MW atomic energy plant area unit is usually safely integrated into the national grid by 2015-2020.

In contrast, the installation worth per MW of an atomic energy plant is US\$ 1.5 million. After getting permission from International Atomic Energy Agency, Russia, France, Asian nations, and China need to grant cash facilitation (Bhowmik and Barua, 2012). The radioactive wastes generated from the atomic energy plant must be placed in fixed containers and unbroken throughout a bunker-like concrete underground storage to form positive against escape. Again, tons of the remaining waste area units usually came back to the fuel cycle and were reprocessed. Bangladesh Atomic Energy Commission (BAEC) will advocate for the developer to arrange fuel for the complete operation quantity for the flexibility reactor and take back the burnt fuel. Therefore, Thus Bangladesh does not have the matter of the major misuse clearance (Hossain, 2021).

\section{BENEFITS}

\section{N-R HES as a Backup to Renewable Energy}

The vital disadvantage of large-scale renewable energy adoption is the need for extra energy backup. Moreover, renewable energies such as solar, wind have a seasonal energy production capacity that would not be enough for whole year energy production in a specific area. At present, the primary sources to produce electricity in the world are coal, diesel, and natural gas. The cost associated with these plants (coal, diesel, natural gas) is mainly operating and running costs. However, in the case of nuclear or hybrid nuclear renewable plants, the major cost is associated with the plant construction cost. Therefore, if these hybrid plants are operated only half of the time, it will not be feasible as the electricity demand will not be fulfilled but the construction cost of the plants remains the same. Nevertheless, there are solutions where nuclear and renewable hybrid technologies can work alongside other sources to maximize efficiency and economic viability.

\section{Nuclear Power to Create Bio-Fuels}

Biofuel is usually produced from biomass feedstock. Almost $70-80 \%$ of the total energy is wasted in the production and transportation processes available throughout the biomass to the biofuel production process (Forsberg, 2009). It is interesting that almost one-half of the energy could be substituted by providing steam at low pressure to ethanol plants out of nuclear plants. This process also reduces the amount of greenhouse gas emissions produced from the ethanol plants. Canada has already implemented this methodology. Further, few developed countries like Russia and Switzerland are already selling low-pressure steam to nearby industries (Forsberg, 2009). Further, Study reported by the Idaho National Laboratory has stated how energy can be utilized to transform all of the carbon atoms in coal into liquid fuel energy without generating carbon dioxide emissions from the coal liquefaction progression nuclear energy (Cherry and Wood, 2006). In this process, the first hydrogen is produced from water using a nuclear reactor, which is then coupled with carbon monoxide with the presence of a specific catalyst to generate high-quality synthetic liquid fuels.

\section{Hydrogen's Role in N-R HES}

When more amount of electric energy is available, hydrogen can be generated from that. To produce liquid fuels from biomass or to fulfill electricity shortage that hydrogen can be supplied later. On the topic of the electrical grid, the essential characterization of hydrogen is that it can be reserved without any cost for as many days as required in bigger reservoir facilities using the same technology which is mainly developed to preserve natural gas. In the United States, seasonal electricity is a serious issue. Commercial technology has been used to preserve hydrogen on large scale to fill up that electricity issue. There is a major thermodynamic incitement which is rather than using electricity alone for producing hydrogen using electricity in conjunction using nuclear reactors. In traditional electrolysis, hydrogen, and oxygen are separated from water using electricity. Hightemperature electrolysis (also called steam electrolysis) is the electrolysis of water where temperature varies between 700 and $1,000^{\circ} \mathrm{C}$ in which electrical energy plays as a driving force to generate oxygen $\left(\mathrm{O}_{2}\right)$ and hydrogen $\left(\mathrm{H}_{2}\right)$ using less power. Energy sources that generate electricity and hydrogen will have comparatively less production cost than energy sources which only generate electricity.

Solar thermal power plants and nuclear reactor generates high-pressure, high-temperature steam. In comparison to "cooler" energy technologies such as solar PV and wind firms, where steam is generated by concentrating sunlight on a central point to warm fluid using mirrors would have financial benefits in the production of hydrogen. Further, the nuclear-wind plants will be very effective to maximize high-temperature electrolysis hydrogen productivity. When windmills are not producing electricity, the nuclear reactor and hydrogen from the reservoir are utilized to generate electricity.

Other systems could be implemented into a N-R-HES system that utilizes hydrogen if there isn't enough wind or sun. Siemens and several other companies have developed solid-oxide hightemperature fuel cells for electricity generation (Forsberg, 2009). 
Fuel cells are being used as stand-alone units and as part of combined-cycle gas turbines, where the fuel cell acts as a "burner" that generates electricity. This technology has an advantage for peak power production because when it is operated in reverse, a high-temperature electrolysis unit produces hydrogen. The system's infrastructure costs can be reduced by using the similar piece of equipment for both hydrogen and electricity production.

\section{STATUS AND ECONOMIC ANALYSIS}

Besides environmental concerns, before moving toward a new technology the return on investment should also be taken into consideration (Suman, 2018). A recently conducted study investigates the economic profitability systems: nuclear power plant, nuclear-wind-hydrogen production facility, and nuclear and wind-combined facility (Sabharwall et al., 2015). Authors reported that hybrid technologies can result in faster returns on investment and these technologies are extremely attractive options for the future.

Though N-R-HES is a very new concept, it has already started gaining popularity around the globe. At a meeting in Vienna hosted by IAEA, around 24 members from 15 member states discussed and analyzed the future of N-R-HES for both electric and non-electric applications. Arif, a nuclear researcher, and designer at Pakistan mentioned that Pakistan is going to implement N-R-HES by installing PV cells and wind farm technology (Patel, 2019). As most of the nuclear plants are located in coastal areas, therefore, integrating PV and wind would be feasible for Pakistan. Some of the countries around the globe such as India, China, Malaysia, Saudi Arabia, Thailand, Canada, Germany, etc. (Table 1) have already installed N-R-HES technologies and successfully running.

The Economics of different configurations of hybrid energy systems of nuclear-renewable depends on the geographic locations and availability of raw materials as well as renewable energies. In the majority of the cases, the overall economic costs of nuclear-hybrid systems are higher when compared to conventional nuclear or renewable energy systems. However, the rate of environmental pollution and the life of system plants are much higher than traditional systems. As a consequence, different nuclear-renewable hybrid technologies are applied for different system configurations. For example, liquid fuels can be used as fuels by utilizing the heat sources from a nuclear reactor during the off-peak times demand of electrical energy. The necessary cost of liquid fuel methanol production was around $10 \%$ higher than the traditional configuration of a non-hybrid system where the use of available resources is more effective and the generation of emissions is low (Cherry et al., 2012a).

In another study, it is obtained that the cost economics of the configurations of a nuclear reactor with a system of storage to make balancing of the variation of wind-generated electricity is more profitable than traditional wind energy system $(20 \%$ penetrations). In these technologies, an excess amount of heat from a nuclear reactor is supplied to a chemical plant where electricity is produced from wind energy. By increasing the number of penetrations, it is possible to increase the profit when compared to a conventional system. In addition, these configurations are more penetrative than conventional windenergy systems. Additionally, the dynamic responses of these hybrid systems are high when compared to renewable energy systems (Garcia et al., 2013a,b).

The up-gradation of coal and wind sources of energy is done through the use of hybrid configurations of nuclear-renewable energy sources. In these cases, the heat from nuclear reactors and systems are utilized to generate electricity, gasoline through the coal (Cherry et al., 2012b). It is found that when the penetration of wind energy is exceeded $\sim 30 \%$ of the total production of electricity then the rate of internal return of the energy of hybrid technologies is high when compared to traditional energy systems (Bragg-Sitton et al., 2013).

There are several economic concerns that may hinder the progress of hybrid nuclear renewable energy systems. Due to high capital requirements and demand, the interest of private investors is low. Construction time and meeting regulatory principles are usually the root causes of rising cost uncertainties (Difiglio and Wanner, 2013). These are the main reasons for fewer running N-R-HES plants so far. Statistics show that over the few decades, the cost of PV technology has reduced significantly. However, the capital and running cost of nuclear is yet high compared to other several energy sources, though reduced in recent years. However, estimating the overall cost of the life cycle precisely is not possible, yet the Levelized Cost of Electricity (LCOE) method is an effective way to predict the overall cost as this process considers the capital, operation, and running cost of a plant for an entire lifecycle. Energy Information Administration (EIA) calculated using LCOE that the total cost of a nuclear plant can be around \$86.1/MWh and \$118.6/MWh for a solar PV plant, in 2019. The organization however predicted that the overall cost for nuclear and PV plants in 2020 would be around \$96.2/MWh and \$58.1/MWh, respectively (U. S. Energy Information Administration, 2018). Interesting to note that, this information represents a $10 \%$ price hike in nuclear and almost $50 \%$ price reduction in solar PV. However, It is necessary to take into consideration that these prices are estimations and along with these predictions other parameters such as climate, government policies and rules may also affect the cost (Asperger, 2018).

\section{Economic Figure of Merit}

The economic figure of merit is defined as those that are commonly used in energy system economic analysis, such as net present value (NPV), payback time, and internal rate of return (IRR). The following is how the term "net present value" (NPV) is described as Chen et al. (2016)-

$$
N P V=\sum_{k=0}^{N} \frac{F C F F_{R k}}{\left(1+r_{R}\right)^{k}}
$$

Where, $N=$ NHES plant operational years, $r_{R}=5 \%$ discount rate (assumption may vary), in computing weighted average cost of capital (WACC), FCFFR $R_{R, k}=\mathrm{k}$ which is the 1 year real discounted free cash flow to firm is defined as follows (Chen et al., 
2016)-

$$
\begin{array}{r}
\operatorname{FCFF}_{R, k}=\left(R_{k}-C_{O \& M, k}-D A_{k}(1+i)^{-k}(1-\sigma)\right) \\
+D A_{k}(1+i)^{-k}-C_{g h g, k}-C A P E X \_k,
\end{array}
$$

Where, $\sigma=$ rate of tax, $\mathrm{i}=$ rate of inflation (3\% assumption), and $C_{A P E X_{k}}$ (capital expense) only occurs when $k=0$, i.e., year 0 , given by

$$
\text { CAPEX }_{k=} C_{c a p}, \sigma
$$

CAPEX $_{k}=0$ for and $C A P E X_{k} \mathrm{k}>0$ for all $k>0$ For each NHES configuration, the capital cost $C_{c a p}$, O\&M cost $C_{O \& M}, \mathrm{k}$, greenhouse gas (GHG) emission cost $C_{g h g, k}$, and revenue $R_{k}$ for year $k$ will be defined in short. Depreciation and amortization $(D A)$ for year $\mathrm{k}$ for deductible tax under modified augmented cost recovery programs, i.e., $D A_{k}$ in Equation (2), can be premeditated-

$$
D A_{k}=\rho \rho_{d a, k}, C_{c a p}
$$

Where, at year $k \rho_{d a, k}$ is the $D A$ rates $^{b}$.

The payback period (PP) is also identified as payback time, is the handful of hours in which the profitability index (PR) equals zero (Farris et al., 2010). Finally, the IRR is defined as the worth of the discount rate $r_{R}$ such that NPV is equal to the IRR for a predefined $N$ years of actions where NPV equals to zero (Moten and Thron, 2013).

\section{AVAILABLE EVALUATION TECHNOLOGIES FOR N-R-HES}

Due to the lower level of emission generations from the hybrid systems of nuclear renewable sources of energy, they are widely used in different regions globally. Therefore, findings of the techno-economic configurations of the systems of nuclear renewable resources are significant. It is also significant to find the best way required in a specific situation. However, to find this analysis, it is required to know different tools used in computer and computational models. Hence, this section of the paper presents different tools, arithmetical models, and software required for the analysis of a techno-economic aspect of hybrid systems of nuclear renewable sources of energy (Ma et al., 2018a).

Several computer tools and system models are needed for techno-economic analysis on regional, national, and international levels. Generally, by analyzing the characteristics of different available tools and optimization models, the necessary framework of hybrid systems can be determined. Proper analysis of these tools helps to identify the effective approaches among several suitable processes. Table 5 presents the required tools, software, and models for the techno-economic aspect of hybrid systems of nuclear renewable sources.

\section{FUTURE RECOMMENDATIONS}

Different types of hybrid energy systems can be demonstrated by revealing their most promising aspects by analyzing the cost-effectiveness and conceptual design. Lucid understanding is required in differentiating between the challenges during the commissioning and operational life span which varies for the different subsystems. This clear concept leads to identify the required renovations and up-gradation along with determining the opportunities to adapt the system with emerging market needs.

Dramatic fluctuations of different products result in regulating the project economics. Hence, the requirement for the hybrid system cannot be determined only by analyzing the current scenario of technologies and available tools engaged in designing and operation. Introducing new tools in design not only facilitates the system design in controlling the production but also could lead to a proper understanding of commercial feedback including system flexibility and storage capacity.

Since the initial investments for establishing the potential nuclear hybrid system are huge, the technologies which could reduce the project development cost are favorable. Those developed technologies should consist of some flexibility in construction and transformation so that the expansion of systems can be facilitated while increasing the demands. Besides, risk management should be at an improved level for reducing the complexity and bringing up a developed control system.

Environmental impact can be assessed during the operation life-cycle of a hybrid energy system. Emission analysis and proper utilization of resources should be included in this assessment in order to determine and develop the accuracy of the life cycle at varying the different capacity factors.

\section{CONCLUSION}

N-R-HES systems are combined facilities that include nuclear reactor, renewable energy system, and industrial processes that at the same time can ensure grid flexibility, emission reduction, and economic viability. The present study reviewed the various aspects of N-R-HES systems in detail along with configurations, interconnections, core components, plant and reactor licensing, benefits, and economic feasibility. The study also summarized the available N-R-HES evaluation technologies along with their features and advantages. The major advantages of the study are pointed below:

- The combined systems overcome some major demerits of the individual systems while operating as combined power generation sources.

- The components needed for hybrid systems are already mature though the N-R-HES systems have not yet practically commercialized.

- Renewable energy systems are readily accepted by the public while nuclear is not yet widely accepted. Integration of these two sources will not only ease the appreciation of the public but also make power production continuous.

- Biofuels and hydrogen can be produced as supplementary products or output from these hybrid systems. 
TABLE 5 | Different computer tools, software, methods, and optimization models for systems of hybrid nuclear renewable sources.

\begin{tabular}{|c|c|c|c|c|}
\hline Tools name & Applied method & Type of analysis & Time-step & References \\
\hline EnergyPLAN & Considered wind energy & $\begin{array}{l}\text { Scenario of } 100 \% \text { sources of renewable } \\
\text { energy }\end{array}$ & Hourly & $\begin{array}{l}\text { Connolly and } \\
\text { Mathiesen, } 2014\end{array}$ \\
\hline $\begin{array}{l}\text { Optimization model based on } \\
\text { MATLAB }\end{array}$ & $\begin{array}{l}\text { Photovoltaic and wind energy } \\
\text { consideration }\end{array}$ & $\begin{array}{l}\text { Scenario of } 100 \% \text { sources of renewable } \\
\text { energy }\end{array}$ & Hourly & $\begin{array}{l}\text { Weiss et al., } \\
2017\end{array}$ \\
\hline Multi-mode method & $\begin{array}{l}\text { Photovoltaic, concentrated solar panel, } \\
\text { wind energy consideration }\end{array}$ & Scenario of $100 \%$ renewable energy & Hourly & $\begin{array}{l}\text { Barbosa et al., } \\
2017\end{array}$ \\
\hline Balmorel & Considered wind generated power & $\begin{array}{l}\text { Integrate renewable sources of energy with } \\
\text { the nuclear reactors based on optimization } \\
\text { through linear process }\end{array}$ & Timely & $\begin{array}{l}\text { Ea Energy } \\
\text { Analyses, } 2007\end{array}$ \\
\hline GENESYS optimization model & $\begin{array}{l}\text { Optimized based on photovoltaic, wind, } \\
\text { and hydropower energy }\end{array}$ & Use hierarchical process based on time & Timely & $\begin{array}{l}\text { Bussar et al., } \\
2014\end{array}$ \\
\hline REMod-D model & $\begin{array}{l}\text { Photovoltaic, hydropower, and wind } \\
\text { energy analysis }\end{array}$ & $\begin{array}{l}\text { Simulate } 100 \% \text { renewable energy sources } \\
\text { through mathematical optimizer }\end{array}$ & Hourly & $\begin{array}{l}\text { Palzer and } \\
\text { Henning, } 2014\end{array}$ \\
\hline $\begin{array}{l}\text { MRESOM (optimization of } \\
\text { multi-region system of energy) }\end{array}$ & $\begin{array}{l}\text { Photovoltaic, concentrated solar power } \\
\text { system, and wind sources of energy }\end{array}$ & $\begin{array}{l}\text { Simulate } 100 \% \text { renewable energy sources } \\
\text { take as a global average }\end{array}$ & $\begin{array}{l}\text { Hourly electric } \\
\text { load }\end{array}$ & $\begin{array}{l}\text { Pleßmann et al., } \\
2014\end{array}$ \\
\hline ENPEP-BALANCE & $\begin{array}{l}\text { Solar, biomass, hydroelectric, wind, } \\
\text { geothermal }\end{array}$ & $\begin{array}{l}\text { Projections of energy based on the level of } \\
\text { emissions }\end{array}$ & Hourly & $\begin{array}{l}\text { Mirsagedis et al., } \\
2004\end{array}$ \\
\hline Multi-mode analysis & $\begin{array}{l}\text { Solar, wind, biogas, hydrogen, biomass } \\
\text { with } 100 \% \text { renewable energy sources }\end{array}$ & Analysis based on cost effectivity & Hourly & $\begin{array}{l}\text { Gulagi et al., } \\
2017\end{array}$ \\
\hline AEOLIUS & Bottom-up process of simulation & Optimization and simulation tool & Timely (minutes) & Ma et al., 2018a \\
\hline Balmorel & Linear method of optimization & Balancing and optimization tool & Hourly & Ma et al., 2018a \\
\hline WILMAR & Use wind sources of power & $\begin{array}{l}\text { Optimized based on the penetration of wind } \\
\text { energy }\end{array}$ & Hourly & $\begin{array}{l}\text { Weber et al., } \\
2009\end{array}$ \\
\hline Top-down method & $\begin{array}{l}\text { Photovoltaic, wind, hydroelectric, and } \\
\text { biomass sources of energy }\end{array}$ & $\begin{array}{l}100 \% \text { renewable sources of energy based on } \\
\text { the resilience of post-disaster }\end{array}$ & Yearly & $\begin{array}{l}\text { Esteban and } \\
\text { Portugal-Pereira, } \\
2014\end{array}$ \\
\hline INFORSE & $\begin{array}{l}\text { Model based on input and output of the } \\
\text { system }\end{array}$ & $\begin{array}{l}\text { Optimization tool that can be used for } \\
\text { balancing as well }\end{array}$ & Yearly & Ma et al., 2018a \\
\hline EMPS & $\begin{array}{l}\text { Algorithm based on stochastic and } \\
\text { network process }\end{array}$ & $\begin{array}{l}\text { Optimization tool that can be used through } \\
\text { stochastic process }\end{array}$ & Weekly & Ma et al., 2018a \\
\hline EnergyPRO & Different sources of renewable energy & $\begin{array}{l}\text { Optimization tool that can be used through } \\
\text { energy integration }\end{array}$ & Timely (minutes) & Ma et al., 2018a \\
\hline HOMER & $\begin{array}{l}\text { Different sources of renewable and } \\
\text { grid-connected sources of energy use to } \\
\text { meet up the energy }\end{array}$ & $\begin{array}{l}\text { Optimization tool that can work through cost } \\
\text { of energy and uncertainty }\end{array}$ & Timely (minutes) & Ma et al., 2018a \\
\hline $\begin{array}{l}\text { Python model through } \\
\text { programming }\end{array}$ & $\begin{array}{l}\text { Photovoltaic, wind, hydroelectric, and } \\
\text { biomass sources of energy are used with } \\
\text { minimum cost of electricity }\end{array}$ & $\begin{array}{l}\text { Simulation with } 100 \% \text { renewable sources of } \\
\text { energy by considering the minimum cost of } \\
\text { energy and characteristic of lower risk }\end{array}$ & Hourly & $\begin{array}{l}\text { Elliston et al., } \\
2014\end{array}$ \\
\hline NEMO & $\begin{array}{l}\text { Photovoltaic, wind, biomass, ocean, and } \\
\text { geothermal sources are analyzed with } \\
\text { lower cost }\end{array}$ & $\begin{array}{l}\text { Simulation with } 100 \% \text { renewable sources of } \\
\text { energy based on the levelized cost }\end{array}$ & Hourly & $\begin{array}{l}\text { Blakers et al., } \\
2017\end{array}$ \\
\hline ETEM & Follow linear mode of programming & $\begin{array}{l}\text { Optimization as well as simulation tool based } \\
\text { on available sources of energy for user } \\
\text { defined manner }\end{array}$ & $\begin{array}{l}\text { Timely (user } \\
\text { defined) }\end{array}$ & Ma et al., 2018a \\
\hline MODEST & Follow linear mode of programming & $\begin{array}{l}\text { Optimization as well as simulation tool based } \\
\text { on available seasonal, daily, or even weekly } \\
\text { sources of energy }\end{array}$ & $\begin{array}{l}\text { Timely } \\
\text { (seasonal, } \\
\text { weekly, and } \\
\text { daily) }\end{array}$ & Ma et al., 2018b \\
\hline
\end{tabular}

- By analyzing the characteristics of different available computer tools and optimization models, the necessary framework of $\mathrm{N}-\mathrm{R}-\mathrm{HES}$ systems can be determined.

- To commercialize N-R-HES systems, further systems analysis, technical development and optimization of the concepts, and analysis of economic viability are necessary.

\section{AUTHOR CONTRIBUTIONS}

MA: conceptualization, methodology, data curation, writingoriginal draft preparation, visualization, investigation, and writing-reviewing and editing. MTI: conceptualization, investigation, methodology, and writing-reviewing and editing. FR: data curation, validation, writing-original 
draft preparation, and writing-review and editing. KM: data curation, investigation, and validation. NM: investigation, validation, and writing-original draft

\section{REFERENCES}

Adamantiades, A., and Kessides, I. (2009). Nuclear power for sustainable development: current status and future prospects. Energy Policy 37, 5149-5166. doi: 10.1016/j.enpol.2009.07.052

Adler, D. B., Jha, A., and Severnini, E. (2020). Considering the nuclear option: hidden benefits and social costs of nuclear power in the US since 1970. Resour. Energy Econ. 59:101127. doi: 10.1016/j.reseneeco.2019.101127

Agyekum, E. B., Ansah, M. N. S., and Afornu, K. B. (2020). Nuclear energy for sustainable development: SWOT analysis on Ghana's nuclear agenda. Energy Rep. 6, 107-115. doi: 10.1016/j.egyr.2019.11.163

Ahmad, J., Imran, M., Khalid, A., Iqbal, W., Ashraf, S. R., Adnan, M., et al. (2018). Techno economic analysis of a wind-photovoltaic-biomass hybrid renewable energy system for rural electrification: a case study of Kallar Kahar. Energy 148, 208-234. doi: 10.1016/j.energy.2018.01.133

Amer, M., Namaane, A., and M'sirdi, N. (2013). Optimization of hybrid renewable energy systems (HRES) using PSO for cost reduction. Energy Procedia 42, 318-327. doi: 10.1016/j.egypro.2013. 11.032

Amui, L. B. L., Jabbour, C. J. C., Jabbour, A. B. L. D. S., and Kannan, D. (2017). Sustainability as a dynamic organizational capability: a systematic review and a future agenda toward a sustainable transition. J. Clean. Prod. 142, 308-322. doi: 10.1016/j.jclepro.2016.07.103

Anoune, K., Bouya, M., Astito, A., and Abdellatif, A. B. (2018). Sizing methods and optimization techniques for PV-wind based hybrid renewable energy system: a review. Renew. Sustain. Energy Rev. 93, 652-673. doi: 10.1016/j.rser.2018. 05.032

Anwar, K., Deshmukh, S., and Mustafa Rizvi, S. (2020). Feasibility and sensitivity analysis of a hybrid photovoltaic/wind/biogas/fuel-cell/diesel/battery system for off-grid rural electrification using homer. J. Energy Resour Technol. 142:061307. doi: 10.1115/1.4045880

Apergis, N., Payne, J. E., Menyah, K., and Wolde-Rufael, Y. (2010). On the causal dynamics between emissions, nuclear energy, renewable energy, and economic growth. Ecol. Econ. 69, 2255-2260. doi: 10.1016/j.ecolecon.2010.06.014

Arefin, M. A., Nabi, M. N., Sadeque, S., and Gudimetla, P. (2021). Incorporating sustainability in engineering curriculum: a study of the Australian universities. Int. J. Sustain. Higher Educ. 576-598. doi: 10.1108/IJSHE-07-2020-0271

Ashok, S. (2007). Optimised model for community-based hybrid energy system. Renew. Energy 32, 1155-1164. doi: 10.1016/j.renene.2006.04.008

Askarzadeh, A., and dos Santos Coelho, L. (2015). A novel framework for optimization of a grid independent hybrid renewable energy system: a case study of Iran. Solar Energy 112, 383-396. doi: 10.1016/j.solener.2014.12.013

Asperger, L. (2018). Hybrid Nuclear-Renewable Power Plants. Submitted as Coursework for PH241. Stanford, CA: Stanford University.

Asplund, R. W. (2008). Profiting From Clean Energy: A Complete Guide to Trading Green in Solar, Wind, Ethanol, Fuel Cell, Carbon Credit Industries, and More. Vol. 307. John Wiley \& Sons.

Awan, A. B. (2019). Performance analysis and optimization of a hybrid renewable energy system for sustainable NEOM city in Saudi Arabia. J. Renew. Sustain. Energy 11:025905. doi: 10.1063/1.5071449

Baker, T., Epiney, A. S., Rabiti, C., and Shittu, E. (2018). Optimal sizing of flexible nuclear hybrid energy system components considering wind volatility. Appl. Energy 212, 498-508. doi: 10.1016/j.apenergy.2017.12.061

Barbir, F. (2012). PEM Fuel Cells: Theory and Practice. Academic Press.

Barbosa, L. D. S. N. S., Bogdanov, D., Vainikka, P., and Breyer, C. (2017). Hydro, wind and solar power as a base for a $100 \%$ renewable energy supply for South and Central America. PLoS ONE 12:e0173820. doi: 10.1371/journal.pone. 0173820

Belfedhal, S. A., Berkouk, E. M., and Messlem, Y. (2019). Analysis of grid connected hybrid renewable energy system. J. Renew. Sustain. Energy 11:014702. doi: $10.1063 / 1.5054869$ preparation. MII: data curation and investigation. All authors contributed to the article and approved the submitted version.
Bernal-Agustín, J. L., and Dufo-López, R. (2009). Simulation and optimization of stand-alone hybrid renewable energy systems. Renew. Sustain. Energy Rev. 13, 2111-2118. doi: 10.1016/j.rser.2009.01.010

Bhowmik, P., and Barua, S. (2012). Prospect of nuclear power plant in Bangladesh. Gas 70:90.

Blakers, A., Lu, B., and Stocks, M. (2017). 100\% renewable electricity in Australia. Energy 133, 471-482. doi: 10.1016/j.energy.2017.05.168

Boarin, S., Locatelli, G., Mancini, M., and Ricotti, M. E. (2012). Financial case studies on small-and medium-size modular reactors. Nucl. Technol. 178, 218-232. doi: 10.13182/NT12-A13561

Bodansky, D. (2005). "Types of nuclear reactors," in Nuclear Energy: Principles, Practices, and Prospects (New York, NY: Springer New York), 171-192.

Borissova, A., and Popov, D. (2015). Analysis and synthesis of hybrid nuclear-solar power plants. BgNS Trans. 20, 58-61.

Borowy, B. S., and Salameh, Z. M. (1996). Methodology for optimally sizing the combination of a battery bank and PV array in a wind/PV hybrid system. Energy Convers. IEEE Trans. 11, 367-375. doi: 10.1109/60.507648

Bragg-Sitton, S. M., Boardman, R., McKellar, M., Garcia, H., Wood, R., Sabharwall, P., et al. (2013). Value Proposition for Load-Following Small Modular Reactor Hybrid Energy Systems. Idaho Falls, ID: Idaho National Laboratory, INL/EXT13-29298.

Bragg-Sitton, S. M., Boardman, R., Rabiti, C., Suk Kim, J., McKellar, M., Sabharwall, P., et al. (2016). Nuclear-Renewable Hybrid Energy Systems. Technology Development Program Plan. Report Number: INL/EXT-16-38165. Idaho National Laboratory, Oak Ridge National Laboratory.

Breeze, P. (2018). Flywheel. Power System Energy Storage Technologies.

Britiannica. Types of Reactors. Available online at: https://www.britannica.com/ technology/nuclear-reactor/Reactor-safety

Bussar, C., Moss, M., Alvarez, R., Philipp, W., Thien, T., Chen, H., et al. (2014). Optimal allocation and capacity of energy storage systems in a future European power system with $100 \%$ renewable energy generation. Energy Procedia 46, 40-47. doi: 10.1016/j.egypro.2014.01.156

Chaib, A., Achour, D., and Kesraoui, M. (2016). Control of a solar PV/wind hybrid energy system. Energy Procedia 95, 89-97. doi: 10.1016/j.egypro.2016. 09.028

Chen, J., Garcia, H. E., Kim, J. S., and Bragg-Sitton, S. M. (2016). Operations optimization of nuclear hybrid energy systems. Nucl. Technol. 195, 143-156. doi: 10.13182/NT15-130

Chen, M. C., Anderson, J. R., and Sohn, M. H. (2001). "What can a mouse cursor tell us more? Correlation of eye/mouse movements on web browsing," in CHI'01 Extended Abstracts on Human Factors in Computing Systems. doi: $10.1145 / 634067.634234$

Cherry, R. S., Aumeier, S. E., and Boardman, R. D. (2012a). Large hybrid energy systems for making low $\mathrm{CO}_{2}$ load-following power and synthetic fuel. Energy Environ. Sci. 5, 5489-5497. doi: 10.1039/C1EE02731J

Cherry, R. S., Breckenridge, R. P., Boardman, R. D., Bell, D., Foulke, T., and Lichtenberger, J. (2012b). Preliminary Feasibility of Value-Added Products From Cogeneration and Hybrid Energy Systems in Wyoming. Idaho National Laboratory (INL).

Cherry, R. S., and Wood, R. A. (2006). Use of a Nuclear High-Temperature Gas Reactor in a Coal-to-Liquids Process. Idaho National Laboratory.

Chong, W., Naghavi, M. S., Poh, S. C., Mahlia, T. M. I., and Pan, K. C. (2011). Techno-economic analysis of a wind-solar hybrid renewable energy system with rainwater collection feature for urban high-rise application. Appl. Energy 88, 4067-4077. doi: 10.1016/j.apenergy.2011.04.042

Christiansen, L. J., and Rostrup-Nielsen, J. (2011). Concepts in Syngas Manufacture (Catalytic Science Series). World Scientific.

Cochran, J., Bird, L., Heeter, J., and Arent, D. J. (2012). Integrating Variable Renewable Energy in Electric Power Markets. Best Practices From International Experience. Golden, CO: National Renewable Energy Lab (NREL). doi: 10.2172/1219661 
Connolly, D., and Mathiesen, B. V. (2014). A technical and economic analysis of one potential pathway to a $100 \%$ renewable energy system. Int. J. Sustain. Energy Plann. Manage. 1, 7-28. doi: 10.5278/ijsepm.2014.1.2

Das, B. K., Hasan, M., and Rashid, F. (2021). Optimal sizing of a grid-independent PV/diesel/pump-hydro hybrid system: a case study in Bangladesh. Sustain. Energy Technol. Assessments 44:100997. doi: 10.1016/j.seta.2021.100997

Das, M., Singh, M. A. K., and Biswas, A. (2019). Techno-economic optimization of an off-grid hybrid renewable energy system using metaheuristic optimization approaches-case of a radio transmitter station in India. Energy Convers. Manage. 185, 339-352. doi: 10.1016/j.enconman.2019.01.107

Difiglio, C., and Wanner, B. (2013). "Economics of nuclear power in liberalized power markets," in International Seminar on Nuclear War and Planetary Emergencies-45th Session: The Role of Science in the Third Millennium (World Scientific).

Ea Energy Analyses (2007). 50\% Wind Power in Denmark by 2025-English Summary. Copenhagen: Ea Energy Analyses.

Elkadeem, M. R., Wang, S., Sharshir, S. W., and Atia, E. G. (2019). Feasibility analysis and techno-economic design of grid-isolated hybrid renewable energy system for electrification of agriculture and irrigation area: a case study in Dongola, Sudan. Energy Convers. Manage. 196, 1453-1478. doi: 10.1016/j.enconman.2019.06.085

Elliston, B., MacGill, I., and Diesendorf, M. (2014). Comparing least cost scenarios for $100 \%$ renewable electricity with low emission fossil fuel scenarios in the Australian National Electricity Market. Renew. Energy 66, 196-204. doi: $10.1016 /$ j.renene.2013.12.010

Esteban, M., and Portugal-Pereira, J. (2014). Post-disaster resilience of a $100 \%$ renewable energy system in Japan. Energy 68, 756-764. doi: 10.1016/j.energy.2014.02.045

Farris, P. W., Bendle, N., Pfeifer, P. E., and Reibstein, D. (2010). Marketing Metrics: The Definitive Guide to Measuring Marketing Performance. Pearson Education.

Fernández-Arias, P., Vergara, D., and Orosa, J. A. (2020). A global review of PWR nuclear power plants. Appl. Sci. 10:4434. doi: 10.3390/app10134434

Forsberg, C. (2009). The real path to green energy: hybrid nuclear-renewable power. Bull. Atomic Sci. 65-71. doi: 10.2968/065006007

Fulzele, J., and Dutt, S. (2012). Optimium planning of hybrid renewable energy system using HOMER. Int. J. Electr. Computer Eng. 2:68. doi: 10.11591/ijece.v2i1.157

Garcia, H. E., Mohanty, A., Lin, W., and Cherry, R. S. (2013a). Dynamic analysis of hybrid energy systems under flexible operation and variable renewable generation-Part I: dynamic performance analysis. Energy 52, 1-16. doi: 10.1016/j.energy.2013.01.022

Garcia, H. E., Mohanty, A., Lin, W., and Cherry, R. S. (2013b). Dynamic analysis of hybrid energy systems under flexible operation and variable renewable generation-Part II: dynamic cost analysis. Energy 52, 17-26. doi: 10.1016/j.energy.2012.11.032

Getty, I. A. E. A., National University of Singapore, Oak Ridge National Laboratory, and Rosatom (2020). Nuclear Technology Review. GC(64)/INF/2. Austria: IAEA.

Gulagi, A., Choudhary, P., Bogdanov, D., and Breyer, C. (2017). Electricity system based on $100 \%$ renewable energy for India and SAARC. PLOS ONE 12:e0180611. doi: 10.1371/journal.pone.0180611

Halabi, L. M., and Mekhilef, S. (2018). Flexible hybrid renewable energy system design for a typical remote village located in tropical climate. J. Clean. Prod. 177, 908-924. doi: 10.1016/j.jclepro.2017.12.248

Hansen, K., Breyer, C., and Lund, H. (2019). Status and perspectives on $100 \%$ renewable energy systems. Energy 175, 471-480. doi: 10.1016/j.energy.2019.03.092

Hashemian, H. M. (2011). On-line monitoring applications in nuclear power plants. Progress Nucl. Energy 53, 167-181. doi: 10.1016/j.pnucene.2010.08.003

Heydari, A., and Askarzadeh, A. (2016). Techno-economic analysis of a $\mathrm{PV} / \mathrm{biomass} /$ fuel cell energy system considering different fuel cell system initial capital costs. Solar Energy 133, 409-420. doi: 10.1016/j.solener.2016.04.018

Hoque, M. E., and Rashid, F. (2021). Gasification Process Using Downdraft Fixed-Bed Gasifier for Different Feedstock, in Gasification. IntechOpen. doi: 10.5772/intechopen.96227

Hossain, D. A. (2021). Urgency of nuclear power in Bangladesh. The Daily Star.

Husain, S., and Shrivastava, N. A. (2020). "Stand-alone hybrid renewable energy system: optimization and sensitivity analysis," in 2020
International Conference on Electrical and Electronics Engineering (ICE3) (Gorakhpur: IEEE).

IEE (2005). An Environment \& Energy FactFile Provided by the IEE. Nuclear Reactor Types. Available online at: http://large.stanford.edu/courses/2013/ ph241/kallman1/docs/nuclear_reactors.pdf

Institute for Energy and Environmental Research. Types of Nuclear Reactors. Available online at: https://ieer.org/resource/classroom/types-of-nuclearreactors

International Atomic Energy Agency. Amendment to the Convention on the Physical Protection of Nuclear Material, in INFCIRC/274/Rev.1/Mod.12016.

International Atomic Energy Agency. Convention on Nuclear Safety, in IAEA - INFC1RC/441994.

International Atomic Energy Agency. Convention on the Physical Protection of Nuclear Materia, in IAEA- INFCIRC/274/Rev. 11980.

International Atomic Energy Agency. The Joint Convention on the Safety of Spent Fuel Management and on the Safety of Radioactive Waste Management, in INFCIRC/5461997.

Kalinci, Y., Hepbasli, A., and Dincer, I. (2015). Techno-economic analysis of a stand-alone hybrid renewable energy system with hydrogen production and storage options. Int. J. Hydrogen Energy 40, 7652-7664. doi: 10.1016/j.ijhydene.2014.10.147

Kasaeian, A., Razmjoo, A., Shirmohammadi, R., Pourfayaz, F., and Sumper, A. (2020). Deployment of a stand-alone hybrid renewable energy system in coastal areas as a reliable energy source. Environ. Prog. Sustain. Energy 39:e13354. doi: 10.1002/ep.13354

Katsigiannis, Y., Georgilakis, P., and Karapidakis, E. (2010). Multiobjective genetic algorithm solution to the optimum economic and environmental performance problem of small autonomous hybrid power systems with renewables. Renew. Power Gener. IET 4, 404-419. doi: 10.1049/iet-rpg.2009. 0076

Kavlak, G., McNerney, J., and Trancik, J. E. (2018). Evaluating the causes of cost reduction in photovoltaic modules. Energy Policy 123, 700-710. doi: 10.1016/j.enpol.2018.08.015

Keller, M. F. (2011). Hybrid Integrated Energy Production Process. Google Patents.

Khan, M. A., Rehman, S., and Al-Sulaiman, F. A. (2018). A hybrid renewable energy system as a potential energy source for water desalination using reverse osmosis: a review. Renew. Sustain. Energy Rev. 97, 456-477. doi: 10.1016/j.rser.2018.08.049

Khare, V., Nema, S., and Baredar, P. (2017). Optimisation of the hybrid renewable energy system by HOMER, PSO and CPSO for the study area. Int. J. Sustain. Energy 36, 326-343. doi: 10.1080/14786451.2015.1017500

Krishan, O., and Suhag, S. (2019). Techno-economic analysis of a hybrid renewable energy system for an energy poor rural community. J. Energy Storage 23, 305-319. doi: 10.1016/j.est.2019.04.002

Kruangpradit, P., and Tayati, W. (1996). Hybrid renewable energy system development in Thailand. Renew. Energy 8, 514-517. doi: 10.1016/0960-1481(96)88910-5

Luna-Rubio, R., Trejo-Perea, M., Vargas-Vazquez, D., and Rios-Moreno, G. J. (2012). Optimal sizing of renewable hybrids energy systems: a review of methodologies. Solar Energy 86, 1077-1088. doi: 10.1016/j.solener.2011.10.016

Ma, W., Xue, X., and Liu, G. (2018a). Techno-economic evaluation for hybrid renewable energy system: application and merits. Energy 159, 385-409. doi: 10.1016/j.energy.2018.06.101

Ma, W., Xue, X., Liu, G., and Zhou, R. (2018b). Techno-economic evaluation of a community-based hybrid renewable energy system considering site-specific nature. Energy Convers. Manage. 171, 1737-1748. doi: 10.1016/j.enconman.2018.06.109

Mahmoudi, H., Abdul-Wahab, S. A., Goosen, M. F. A., Sablani, S. S., Perret, J., Ouagued, A., et al. (2008). Weather data and analysis of hybrid photovoltaic-wind power generation systems adapted to a seawater greenhouse desalination unit designed for arid coastal countries. Desalination 222, 119-127. doi: 10.1016/j.desal.2007.01.135

Maleki, A., Khajeh, M. G., and Ameri, M. (2016). Optimal sizing of a grid independent hybrid renewable energy system incorporating resource uncertainty, and load uncertainty. Int. J. Electr. Power Energy Syst. 83, 514-524. doi: 10.1016/j.ijepes.2016.04.008

Mayer, M. J., Szilágyi, A., and Gróf, G. (2020). Environmental and economic multi-objective optimization of a household level hybrid 
renewable energy system by genetic algorithm. Appl. Energy 269:115058. doi: 10.1016/j.apenergy.2020.115058

Melorose, J., Perroy, R., and Careas, S. (2015). World Population Prospects. United Nations. p. 587-592.

Menyah, K., and Wolde-Rufael, Y. (2010). $\mathrm{CO}_{2}$ emissions, nuclear energy, renewable energy and economic growth in the US. Energy Policy 38, 2911-2915. doi: 10.1016/j.enpol.2010.01.024

Mirsagedis, S., Conzelmann, G., Georgopoulou, E., Koritarov, V., and Sarafidis, Y. (2004). "Longterm GHG emissions outlook for Greece," in Proceedings of the 6th IAEE European Conference on Modelling in Energy Economics and Policy (Zurich: Citeseer).

Moten, J. M. Jr., and Thron, C. (2013). Improvements on secant method for estimating internal rate of return (IRR). Int. J. Appl. Math. Stat. 42, 84-93.

Murugaperumal, K., and Raj, P. A. D. V. (2019). Feasibility design and technoeconomic analysis of hybrid renewable energy system for rural electrification. Solar Energy 188, 1068-1083. doi: 10.1016/j.solener.2019.07.008

Natarajan, S. K., Kamran,. F., Ragavan, N., Rajesh, R., Jena, R. K., and Suraparaju, S. K. (2019). Analysis of PEM hydrogen fuel cell and solar PV cell hybrid model. Mater. Today Proc. 17, 246-253. doi: 10.1016/j.matpr.2019.06.426

Nuclear Energy Agency (2015). Technology Roadmap E Nuclear Energy.

Nuclear Power in European Union (2021). Available online at: https://www. world-nuclear.org/information-library/country-profiles/others/europeanunion.aspx

Office of Energy Efficiency and Renewable Energy. Hydrogen Production: Electrolysis. Available online at: https://www.energy.gov/eere/fuelcells/ hydrogen-production-electrolysis.Enegry.Gov

Office of Energy Efficiency and Renewable Energy. Hydrogen Production: Thermochemical Water Splitting. Available online at: https://www.energy.gov/ eere/fuelcells/hydrogen-production-thermochemical-water-splitting\#: : text=Thermochemical\%20water\%20splitting\%20processes $\% 20$ use, and $\% 20$ produces $\% 20$ hydrogen $\% 20$ and $\% 20$ oxygen

Orr, F. M. (2015). "Quadrennial technology review," in Proceedings of the International Conference for High Performance Computing, Networking, Storage and Analysis. doi: 10.1145/2807591.2897787

Oyeneyin, B. M., Bali, A., and Adom, E. (2012). "Optimisation of Steam Assisted Gravity Drainage [SAGD] for improved recovery from unconsolidated heavy oil reservoirs," in Advanced Materials Research (Aberdeen: Trans Tech Publications), 1-28.

Palzer, A., and Henning, H.-M. (2014). A comprehensive model for the German electricity and heat sector in a future energy system with a dominant contribution from renewable energy technologies-Part II: results. Renew. Sustain. Energy Rev. 30, 1019-1034. doi: 10.1016/j.rser.2013.11.032

Papaioannou, I. T., Purvins, A., Shropshire, D., and Carlsson, J. (2014). Role of a hybrid energy system comprising a small/medium-sized nuclear reactor and a biomass processing plant in a scenario with a high deployment of onshore wind farms. J. Energy Eng. 140:04013005. doi: 10.1061/(ASCE)EY.1943-7897.0000142

Patel, S. (2019, August 1). How nuclear hybrids could redefine the industry's future. Power. Available online at: www.powermag.com

Pioro, I. (2013). Nuclear Power as a Basis for Future Electricity Production in the World: Generation III and IV Reactors. doi: 10.5772/51916

Pleßmann, G., Erdmann, M., Hlusiak, M., and Breyer, C. (2014). Global energy storage demand for a $100 \%$ renewable electricity supply. Energy Procedia 46, 22-31. doi: 10.1016/j.egypro.2014.01.154

Pravalie, R. (2014). Nuclear weapons tests and environmental consequences: a global perspective. Ambio 43, 729-744. doi: 10.1007/s13280-014-0491-1

Rahman, M. M., Khan, M. M., Ullah, M. A., Zhang, Z., and Kumar, A. (2016). A hybrid renewable energy system for a North American off-grid community. Energy 97, 151-160. doi: 10.1016/j.energy.2015.12.105

Ramesh, M., and Saini, R. P. (2020). Dispatch strategies based performance analysis of a hybrid renewable energy system for a remote rural area in India. J. Clean. Prod. 259, 120697. doi: 10.1016/j.jclepro.2020. 120697

Reddy, B. S., and Assenza, G. B. (2009). The great climate debate. Energy Policy 37, 2997-3008. doi: 10.1016/j.enpol.2009.03.064

Redfoot, E. K., and Borrelli, R. A. (2018). Analysis of nuclear renewable hybrid energy systems modeling and nuclear fuel cycle simulators. Nucl. Technol. 204, 249-259. doi: 10.1080/00295450.2018.1478590
Ruth, M. F., Zinaman, O. R., Antkowiak, M., Boardman, R. D., Cherry, R. S., and Brazilian, M. D. (2014). Nuclear-renewable hybrid energy systems: opportunities, interconnections, and needs. Energy Convers. Manage. 78, 684-694. doi: 10.1016/j.enconman.2013.11.030

Sabharwall, P., Bragg-Sitton, S., Boldon, L., and Blumsack, S. (2015). Nuclear renewable energy integration: an economic case study. Electr. J. 28, 85-95. doi: 10.1016/j.tej.2015.09.003

Sawle, Y., Gupta, S., and Bohre, A. K. (2018). Socio-techno-economic design of hybrid renewable energy system using optimization techniques. Renew. Energy 119, 459-472. doi: 10.1016/j.renene.2017.11.058

Senjyu, T., Hayashi, D., Yona, A., Urasaki, N., and Funabashi, T. (2007). Optimal configuration of power generating systems in isolated island with renewable energy. Renew. Energy 32, 1917-1933. doi: 10.1016/j.renene.2006. 09.003

Shezan, S., Al-Mamoon, A., and Ping, H. (2018). Performance investigation of an advanced hybrid renewable energy system in Indonesia. Environ. Prog. Sustain. Energy 37, 1424-1432. doi: 10.1002/ep.12790

Singh, A., and Baredar, P. (2016). Techno-economic assessment of a solar PV, fuel cell, and biomass gasifier hybrid energy system. Energy Rep. 2, 254-260. doi: 10.1016/j.egyr.2016.10.001

Singh, A., Baredar, P., and Gupta, B. (2017). Techno-economic feasibility analysis of hydrogen fuel cell and solar photovoltaic hybrid renewable energy system for academic research building. Energy Convers. Manage. 145, 398-414. doi: 10.1016/j.enconman.2017.05.014

Singh, S. S., and Fernandez, E. J. E. (2018). Modeling, size optimization and sensitivity analysis of a remote hybrid renewable energy system. Energy 143, 719-731. doi: 10.1016/j.energy.2017.11.053

Spector, J. (2021, January 14). Almost all new US power plants built in 2021 will be carbon-free. A Wood Mackenzie Business.

Suman, S. (2018). Hybrid nuclear-renewable energy systems: a review. J. Clean. Prod. 181, 166-177. doi: 10.1016/j.jclepro.2018.01.262

Suresh, V., Muralidhar, M., and Kiranmayi, R. (2020). Modelling and optimization of an off-grid hybrid renewable energy system for electrification in a rural areas. Energy Rep. 6, 594-604. doi: 10.1016/j.egyr.2020.01.013

Tesfa, B., Mishra, R., Zhang, C., Gu, F., and Ball, A. D. (2013). Combustion and performance characteristics of CI (compression ignition) engine running with biodiesel. Energy 51, 101-115. doi: 10.1016/j.energy.2013. 01.010

The International Renewable Energy Agency (IRENA) (2019). Renewable Capacity Statistics 2019.

Toth, F. L., and Rogner, H.-H. (2006). Oil and nuclear power: past, present, and future. Energy Econ. 28, 1-25. doi: 10.1016/j.eneco.2005.03.004

Trancik, J. E., and Cross-Call, D. (2013). Energy technologies evaluated against climate targets using a cost and carbon trade-off curve. Environ. Sci. Technol. 47, 6673-6680. doi: 10.1021/es304922v

Trippe, F., Frohling, M., Schultmann, F., Stahl, R., and Henrich, E. (2010). Techno-economic analysis of fast pyrolysis as a process step within biomass-to-liquid fuel production. Waste Biomass Valorization 1, 415-430. doi: 10.1007/s12649-010-9039-1

United Nation (2005). International Convention for the Suppression of Acts of Nuclear Terrorism.

Upadhyay, S., and Sharma, M. P. (2014). A review on configurations, control and sizing methodologies of hybrid energy systems. Renew. Sustain. Energy Rev. 38, 47-63. doi: 10.1016/j.rser.2014.05.057

U. S. Department of Energy (2015). Hybrid Nuclear-Renewable Energy Systems.

U. S. Energy Information Administration (2018). Levelized Cost and Levelized Avoided Cost of New Generation Resources in the Annual Energy Outlook 2018. U.S. Energy Information Administration.

U. S. Energy Information Administration (2020). Types of Reactors.

USNRC. Nuclear Power Plant Lisencing Process. Available online at: https://www. nrc.gov/docs/ML0421/ML042120007.pdf

Vaillancourt, K., Labriet, M., Loulou, R., and Waaub, J.-P. (2008). The role of nuclear energy in long-term climate scenarios: an analysis with the world-TIMES model. Energy Policy 36, 2296-2307. doi: 10.1016/j.enpol.2008. 01.015

van de Loosdrecht, J., and Niemantsverdriet, J. W. (2013). Synthesis Gas Chemistry and Synthetic Fuels. Chemical Energy Storage. Available online at: https://www. syngaschem.com/the-chemistry/ 
Vendoti, S., Muralidhar, M., and Kiranmayi, R. (2020). Techno-economic analysis of off-grid solar/wind/biogas/biomass/fuel cell/battery system for electrification in a cluster of villages by HOMER software. Energy Rep. 23, 1-22. doi: 10.1007/s10668-019-00583-2

Walker, K. What Is SynGas? Available online at: https://www.azocleantech.com/ article.aspx?ArticleID=377.AZOCLEANTECH

Wang, R., Xiong, J., He, M. F., Gao, L., and Wang, L. (2020). Multiobjective optimal design of hybrid renewable energy system under multiple scenarios. Renew. Energy 151, 226-237. doi: 10.1016/j.renene.2019. 11.015

Weber, C., Meibom, P., Barth, R., and Brand, H. (2009). "Wilmar: a stochastic programming tool to analyze the large-scale integration of wind energy," in Optimization in the Energy Industry, eds J. Kallrath, P. M. Pardalos, S. Rebennack, and M. Scheidt (Springer), 437-458.

Weiss, O., Bogdanov, D., Salovaara, K., and Honkapuro, S. (2017). Market designs for a $100 \%$ renewable energy system: case isolated power system of Israel. Energy 119, 266-277. doi: 10.1016/j.energy.2016. 12.055

World Nuclear Association (2021). Nuclear Power Reactors.

Zhou, B., Xu, D., Li, C., Chung, C. Y., Cao, Y., Chan, K. W., et al. (2018). Optimal scheduling of biogas-solar-wind renewable portfolio for multicarrier energy supplies. IEEE Trans. Power Syst. 33, 6229-6239. doi: 10.1109/TPWRS.2018.2833496

Conflict of Interest: The authors declare that the research was conducted in the absence of any commercial or financial relationships that could be construed as a potential conflict of interest.

Publisher's Note: All claims expressed in this article are solely those of the authors and do not necessarily represent those of their affiliated organizations, or those of the publisher, the editors and the reviewers. Any product that may be evaluated in this article, or claim that may be made by its manufacturer, is not guaranteed or endorsed by the publisher.

Copyright (c) 2021 Arefin, Islam, Rashid, Mostakim, Masuk and Islam. This is an open-access article distributed under the terms of the Creative Commons Attribution License (CC BY). The use, distribution or reproduction in other forums is permitted, provided the original author(s) and the copyright owner(s) are credited and that the original publication in this journal is cited, in accordance with accepted academic practice. No use, distribution or reproduction is permitted which does not comply with these terms. 